Nevada

Environmental

Restoration

Project

\title{
DOE/NV--582
}

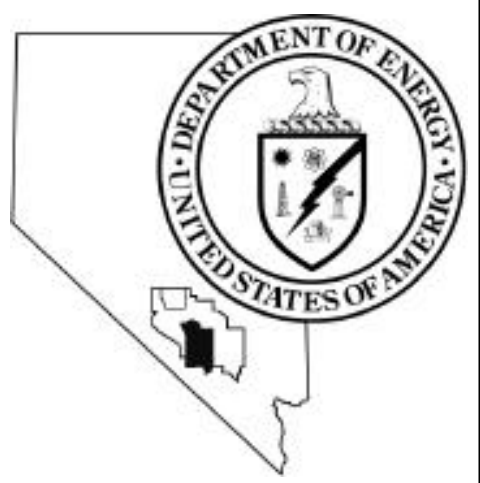

Corrective Action Decision Docum ent/ Closure Report for

Corrective Action Unit 232:

Area 25 Sewage Lagoons,

$N$ evada Test $S$ ite, $N$ evada

Controlled Copy N 0.:

Revision N 0.: 0

December 1999

Approved for public release; further dissemination unlimited.

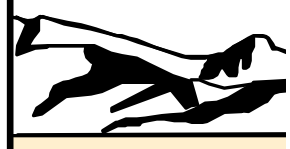

Environm ental Restoration

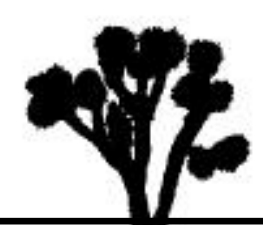

Division 
Available for sale to the public, in paper, from:

\author{
U.S. Department of Commerce \\ National Technical Information Service \\ 5285 Port Royal Road \\ Springfield, VA 22161 \\ phone: (800) 553-6847 \\ fax: (703) 605-6900 \\ email: orders@ntis.fedworld.gov \\ online ordering: http//www.ntis.gov/ordering.htm
}

Available electronically at http://www.doe.gov/bridge.

Available for a processing fee to U.S. Department of Energy and its contractors, in paper, from:

\author{
U.S. Department of Energy \\ Office of Scientific and Technical Information \\ P.O. Box 62 \\ Oak Ridge, TN 37831-0062 \\ phone: (865) 576-8401 \\ fax: (865) 576-5728 \\ email: reports@adonis.osti.gov
}

Reference herein to any specific commercial product, process, or service by trade name, trademark, manufacturer, or otherwise, does not necessarily constitute or imply its endorsement, recommendation, or favoring by the United States Government or any agency thereof or its contractors or subcontractors. 


\title{
CORRECTIVE ACTION DECISION DOCUMENT/ CLOSURE REPORT FOR CORRECTIVE ACTION UNIT 232: AREA 25 SEWAGE LAGOONS, NEVADA TEST SITE, NEVADA
}

\author{
DOE Nevada Operations Office \\ Las Vegas, Nevada
}

Controlled Copy No.:

Revision No.: 0

December 1999

Approved for public release; further dissemination unlimited. 


\section{CORRECTIVE ACTION DECISION DOCUMENT/ \\ CLOSURE REPORT \\ FOR CORRECTIVE ACTION UNIT 232: \\ AREA 25 SEWAGE LAGOONS, NEVADA TEST SITE, NEVADA}

Approved by: $\quad$ Signature Approved

Date: $12 / 23 / 99$

Janet Appenzeller-Wing, Project Manager

Industrial Sites Project

Approved by:

Signature Approved

Date:

$12 / 23 / 99$

Runore C. Wycoff, Division Director

Environmental Restoration Division 


\section{Table of Contents}

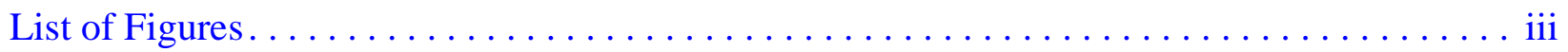

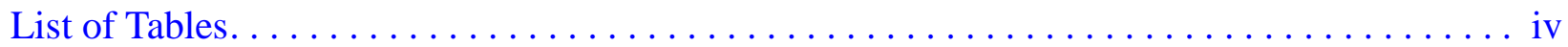

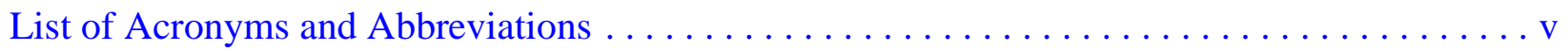

Executive Summary . . . . . . . . . . . . . . . . . . . . . . . . .

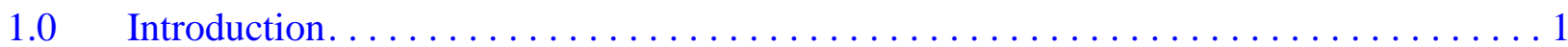

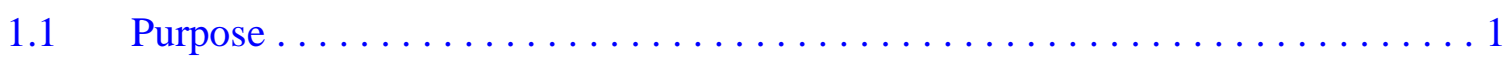

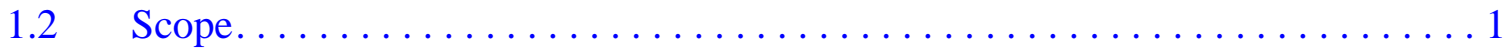

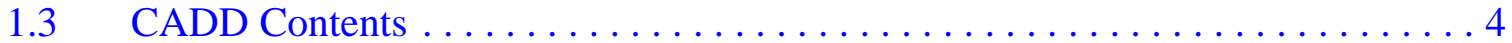

2.0 Corrective Action Investigation Summary $\ldots \ldots \ldots \ldots \ldots \ldots \ldots \ldots \ldots \ldots \ldots \ldots \ldots \ldots \ldots$

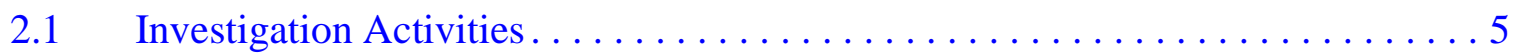

$2.2 \quad$ Results................................... 6

$2.3 \quad$ Need for Corrective Action. . . . . . . . . . . . . . . . . . . . 6

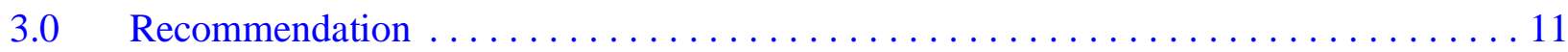

$4.0 \quad$ References..................................... 12

Appendix A - Corrective Action Investigation Report for CAU 232: Area 25 Sewage Lagoons, Nevada Test Site, Nevada

A.1.0 Introduction. . . . . . . . . . . . . . . . . . . .

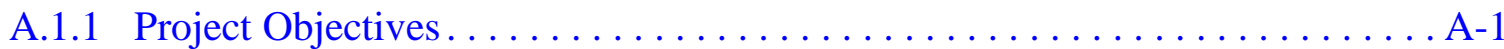

A.1.2 Report Content ........................ A-2

A.2.0 Field Investigation and Sampling Activities. . . . . . . . . . . . . A-3

A.2.1 Site Descriptions and Conditions . . . . . . . . . . . . . . . . . A-3

A.2.2 Sampling Logistics . . . . . . . . . . . . . . . . . . . . A-4

A.2.2.1 Sample Locations . . . . . . . . . . . . . . . . . . A-4

A.2.2.2 Direct-push Sampling. . . . . . . . . . . . . . . A-4

A.2.2.3 Field Screening. . . . . . . . . . . . . . . . . . . A-4

A.2.2.4 Environmental Samples . . . . . . . . . . . . . . . . . . A-6

A.2.2.5 Background Samples . . . . . . . . . . . . . . . . . . A-6

A.2.2.6 Quality Control Samples . . . . . . . . . . . . . . . . A-7

A.2.3 Geology ............................

A.2.4 Hydrology . . . . . . . . . . . . . . . . . . . . A-7

A.3.0 Investigation Results. . . . . . . . . . . . . . . . .

A.3.1 Total Volatile Organic Compound Analytical Results . . . . . . . . . . . . . . A-8

A.3.2 Total Semivolatile Organic Compound Analytical Results . . . . . . . . . . . A-8 


\section{Table of Contents (Continued)}

A.3.3 Total Petroleum Hydrocarbon Results . . . . . . . . . . . . . . . . . A-8

A.3.4 Total RCRA Metals Results . . . . . . . . . . . . . . . . . . . . . . . A-10

A.3.5 Polychlorinated Biphenyl(s) Results . . . . . . . . . . . . . . . . A-10

A.3.6 Total Pesticides Results . . . . . . . . . . . . . . . . . . . . . . A-12

A.3.7 Total Herbicides Results . . . . . . . . . . . . . . . . . . . . . A-12

A.3.8 Isotopic Uranium Results . . . . . . . . . . . . . . . . . A-12

A.3.9 Isotopic Plutonium Results . . . . . . . . . . . . . . . . . A-12

A.3.10 Strontium-90 Results . . . . . . . . . . . . . . . . . . . A-12

A.3.11 Gamma Spectrometry Results . . . . . . . . . . . . . . A-12

A.4.0 Quality Assurance................................. A-15

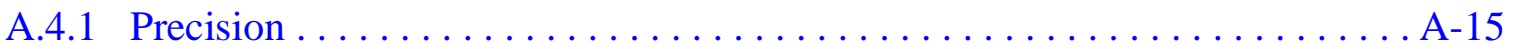

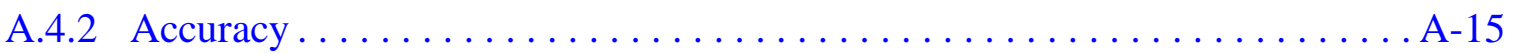

A.4.3 Representativeness . . . . . . . . . . . . . . . . . . . . . . . . . . A-16

A.4.4 Completeness .............................. A-16

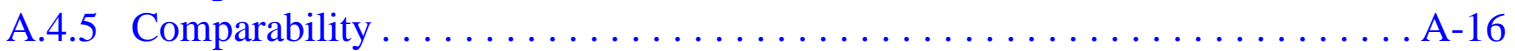

A.4.6 Tier I and Tier II Data Evaluations. . . . . . . . . . . . . . . . A-17

A.4.6.1 Tier I Evaluation. . . . . . . . . . . . . . . . . . $\ldots \ldots$

A.4.6.2 Tier II Evaluation . . . . . . . . . . . . . . . . A-18

A.4.6.3 Tier III . . . . . . . . . . . . . . . . . . . . . . . A-19

A.4.7 Quality Control Samples. .......................... A-20

A.4.7.1 Field Quality Control Samples . . . . . . . . . . . . . . A-20

A.4.7.2 Laboratory Quality Control Samples . . . . . . . . . . . . . . . . . . A-21

A.4.8 Field Nonconformances . . . . . . . . . . . . . . . . . . . A-23

A.4.9 Laboratory Nonconformances $\ldots \ldots \ldots \ldots \ldots \ldots \ldots \ldots \ldots \ldots \ldots \ldots \ldots \ldots \ldots$

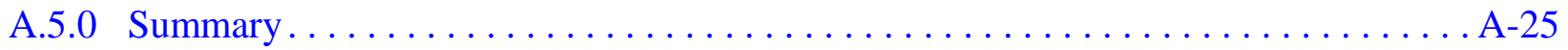

A.6.0 References.................................... A-26

Appendix B - Response to NDEP Comments 


\section{List of Figures}

Number

1-1 Nevada Test Site and CAU 232, Area 25 Sewage Lagoons Location Map, Nye County, Nevada . . . . . . . . . . . . . . . . . . . . 2

1-2 CAU 232, Area 25 Sewage Lagoons, CAS 25-03-01, Nevada Test Site . . . . . . . 3

2-1 Fence and Signs Placed Around Sewage Lagoons Perimeter to Limit Access . . . . . . . . . . . . . . . . . . . . . . . . . . . . . 7

2-2 Manhole-2 is located between the sewage lagoons inlet to the east and outlet to the swale on the west. The manhole was sealed to prohibit access.......8

2-3 Placing Lid on Cemented $\mathrm{MH}-2 \ldots \ldots \ldots \ldots \ldots \ldots \ldots \ldots \ldots$

2-4 Sealing of the Diverter Box Between Test Cell "C" and the Sewage Lagoons . . . . . . . . . . . . . . . . . . . . . . . . . . . 9

2-5 Remaining Outline of the Sealed Diverter Box ................ 9

2-6 CAU 232, Area 25 Sewage Lagoons, Current Site Conditions . . . . . . . . . . . . . . . 10

A.2-1 CAU 232, Area 25 Sewage Lagoons, Sample Locations, Nye County, Nevada . . . . . . . . . . . . . . . . . . . . . . . A-5 


\section{List of Tables}

Number

A.3-1 CAU 232, Area 25 Sewage Lagoons, Sampling Locations and Analyses . . . . . A A-9

A.3-2 Laboratory Analytical Methods Used for Samples Collected at CAU 232, Area 25 Sewage Lagoons, Nevada Test Site

A.3-3 Total RCRA Metals Detected Above Minimum Reporting Limits

CAU 232, Area 25 Sewage Lagoons, Nevada Test Site

A.3-4 Isotopic Uranium Results for CAU 232, Area 25 Sewage Lagoons,

Nevada Test Site

A.3-5 Gamma Spectrometry Results for CAU 232, Area 25 Sewage Lagoons, Nevada Test Site 


\section{List of Acronyms and Abbreviations}

bgs Below ground surface

BN Bechtel Nevada

CADD Corrective Action Decision Document

CAIP Corrective Action Investigation Plan

CAS Corrective Action Site

CAU Corrective Action Unit

CLP Contract Laboratory Program

COC Contaminant(s) of concern

COPC Contaminant(s) of potential concern

CR Closure Report

DOE/NV U.S. Department of Energy, Nevada Operations Office

DQO Data Quality Objective(s)

EPA U.S. Environmental Protection Agency

FFACO Federal Facility Agreement and Consent Order

FSL Field-screening levels

$\mathrm{ft} \quad$ Foot (feet)

ICP Inductively coupled plasma

IDW Investigation-derived waste

in. $\operatorname{Inch}(\mathrm{es})$

LCS Laboratory control sample(s)

mi Mile(s)

$\mathrm{mg} / \mathrm{kg} \quad$ Milligram(s) per kilogram

MH Manhole

MS/MSD Matrix spike/matrix spike duplicate

NDEP Nevada Division of Environmental Protection

NIST National Institute for Standards and Technology

NTS Nevada Test Site 


\section{List of Acronyms and Abbreviations (Continued)}

PAL Preliminary action level(s)

PCB Polychlorinated biphenyl(s)

pCi/g Picocurie(s) per gram

ppm Part(s) per million

$\mathrm{Pu} \quad$ Plutonium

PVC Polyvinyl chloride

QA Quality assurance

QAPP Quality Assurance Project Plan

QC Quality control

RCRA Resource Conservation and Recovery Act

RPD Relative percent difference

SDG Sample delivery group

$\mathrm{Sr} \quad$ Strontium

SSHASP Site-specific Health and Safety Plan

SVOC Semivolatile organic compound(s)

TPH Total petroleum hydrocarbons

U Uranium

VOC Volatile organic compound(s)

$\mu \mathrm{g} / \mathrm{kg} \quad$ Microgram(s) per kilogram

$\% \mathrm{R} \quad$ Percent recovery 


\section{Executive Summary}

This Corrective Action Decision Document/Closure Report has been prepared for Corrective Action Unit 232, Area 25 Sewage Lagoons, in accordance with the Federal Facility Agreement and Consent Order (FFACO, 1996). Corrective Action Unit 232 is located at the Nevada Test Site, Nevada, and is comprised of Corrective Action Site 25-03-01, Sewage Lagoon.

The purpose of this Corrective Action Decision Document/Closure Report is to provide justification for no further action at Corrective Action Unit 232.

The scope of this Corrective Action Decision Document/Closure Report consists of the following tasks:

- Review the current site conditions, including the presence, concentration, and extent of contamination.

- Document closure of the Corrective Action Unit.

A corrective action investigation was performed in July 1999 as set forth in the Corrective Action Investigation Plan for Corrective Action Unit 232: Area 25 Sewage Lagoons, Nevada Test Site, Nevada (DOE/NV, 1999). The corrective action investigation analytical results for total volatile organic compounds, total semivolatile organic compounds, total Resource Conservation and Recovery Act metals, total pesticides, total herbicides, total petroleum hydrocarbons (gasoline and diesel/oil range), polychlorinated biphenyls, isotopic uranium, isotopic plutonium, strontium-90, and gamma-emitting radionuclides did not exceed the preliminary action levels outlined in the Corrective Action Investigation Plan. Details regarding the investigation can be found in Appendix A of this document.

No constituents were identified above preliminary action levels; therefore, no corrective actions are necessary for Corrective Action Unit 232. Best management practice activities were completed and included the installation of a fence and signs to limit access to the lagoons, cementing Manhole Number 2 located between the sewage lagoons and the swale, and cementing the diverter box between Test Cell "C" and the sewage lagoons, closing off the influent and effluent ends of the sewage lagoon piping. 
Therefore, the U.S. Department of Energy, Nevada Operations Office recommends the following:

- No further corrective actions be required.

- $\quad$ No Corrective Action Plan be required.

- A Notice of Completion to the U.S. Department of Energy, Nevada Operations Office is requested from the Nevada Division of Environmental Protection for the closure of Corrective Action Unit 232 (Area 25 Sewage Lagoons [Corrective Action Site 25-03-01, Sewage Lagoons]).

- Corrective Action Unit 232 be moved from Appendix III to Appendix IV of the Federal Facility Agreement and Consent Order.

- No use restrictions are required to be placed on the Corrective Action Unit. 


\subsection{Introduction}

This Corrective Action Decision Document/Closure Report (CADD/CR) has been prepared for Corrective Action Unit (CAU) 232, Area 25 Sewage Lagoons, in accordance with the Federal Facility Agreement and Consent Order (FFACO) that was agreed to by the U.S. Department of Energy, Nevada Operations Office (DOE/NV); the Nevada Division of Environmental Protection (NDEP); and the U.S. Department of Defense (FFACO, 1996). The CADD and CR have been combined into one report because sample data collected during the corrective action investigation showed no evidence of soil contamination at this site. The CADD/CR provides or references the specific information necessary to recommend that no further action is required at Corrective Action Site (CAS) 25-03-01, Sewage Lagoon, within CAU 232.

Corrective Action Unit 232 is located at the Nevada Test Site (NTS) in Nevada. The NTS is approximately 65 miles (mi) northwest of Las Vegas, Nevada (Figure 1-1 and Figure 1-2).

\subsection{Purpose}

This CADD/CR provides justification for no further action at CAU 232. The justification is based on the results of investigative activities conducted in accordance with the Corrective Action Investigation Plan for Corrective Action Unit 232: Area 25 Sewage Lagoons, Nevada Test Site, Nevada (DOE/NV, 1999).

\subsection{Scope}

The scope of this CADD/CR is to justify and recommend that no corrective action is required at CAU 232. To achieve this scope the following actions are required:

- Review the current site conditions, including the presence, concentration, and extent of contamination.

- Document closure of the CAU. 


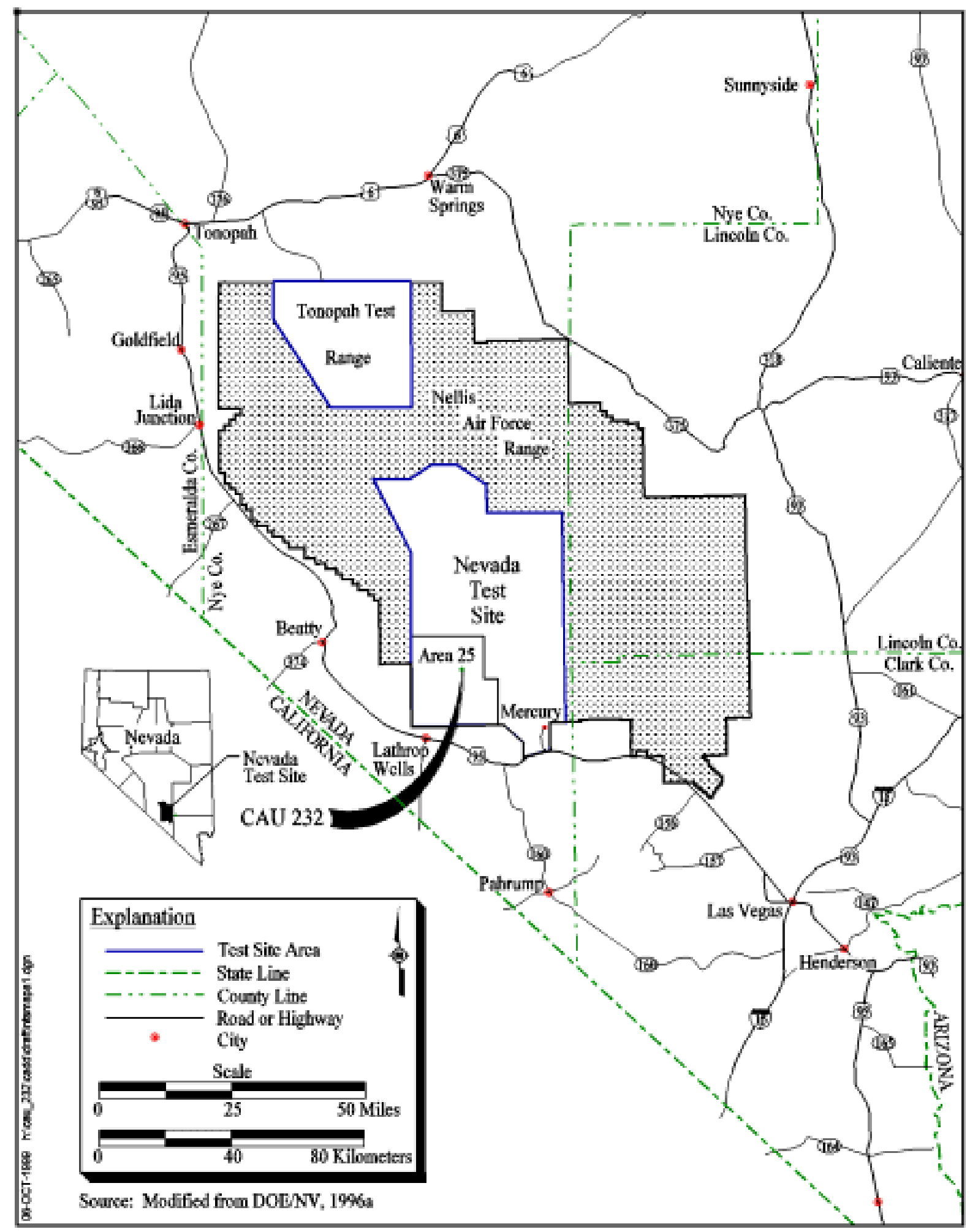

Figure 1-1

Nevada Test Site and CAU 232, Area 25 Sewage Lagoons Location Map, Nye County, Nevada 


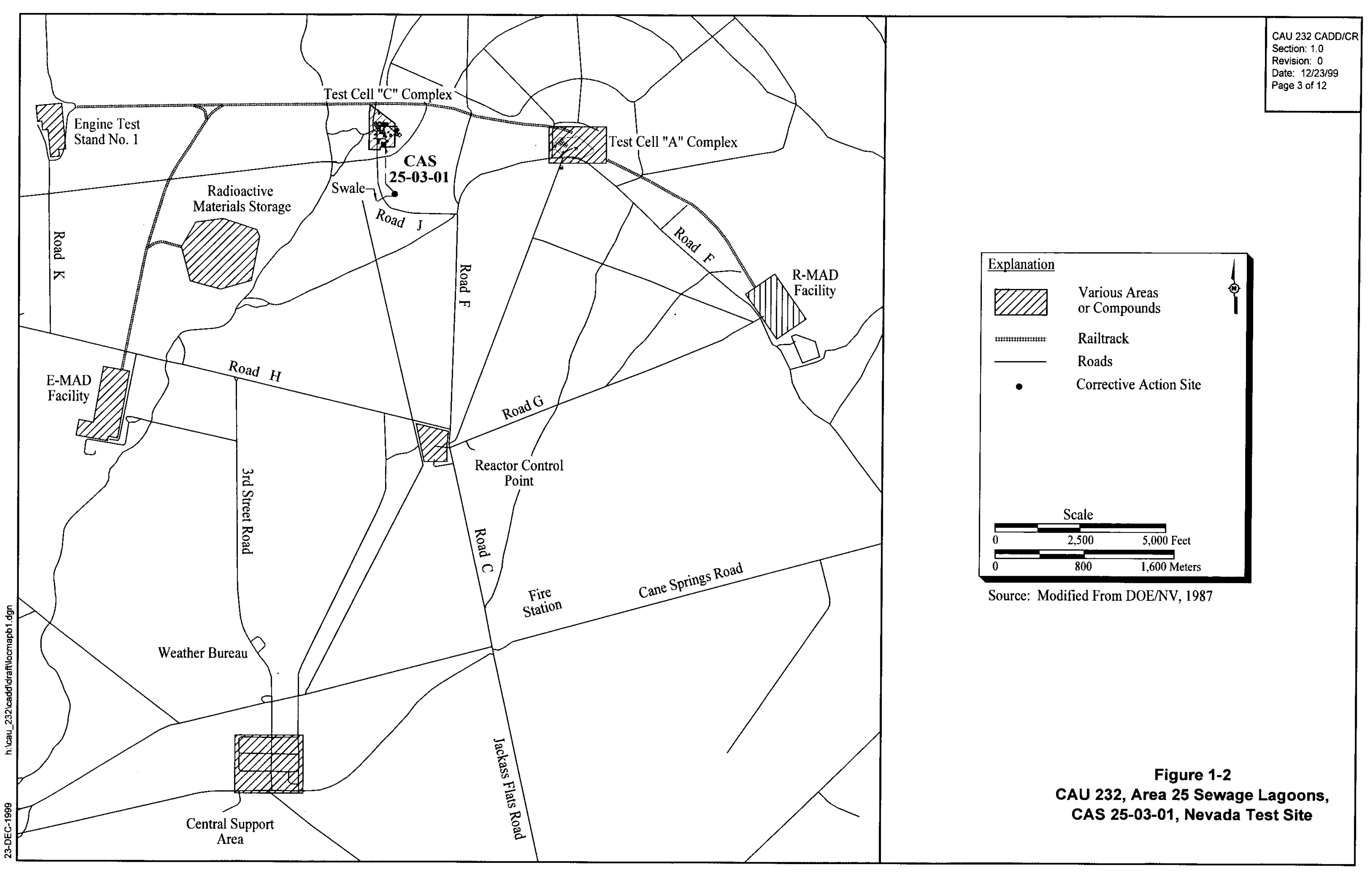




\subsection{CADD Contents}

This CADD/CR is divided into the following sections:

Section 1.0 - Introduction: summarizes the purpose, scope, and contents of this CADD/CR.

Section 2.0 - Corrective Action Investigation Summary: summarizes the investigation field activities, the results of the investigation, and the justification for no further action.

Section 3.0 - Recommendation: recommends no further action and closure of the CAU.

Section 4.0 - References: provides a list of all referenced documents.

Appendix A: Corrective Action Investigation Report for CAU 232: Area 25 Sewage Lagoons, Nevada Test Site, Nevada.

All work was performed in accordance with the following documents:

- Corrective Action Investigation Plan (CAIP) (DOE/NV, 1999)

- Industrial Sites Quality Assurance Project Plan (QAPP) (DOE/NV, 1996b)

- FFACO (FFACO, 1996)

- Project Management Plan (DOE/NV, 1994) 


\subsection{Corrective Action Investigation Summary}

The following sections describe and summarize the results of the investigation activities conducted at CAU 232. For detailed investigation results, please refer to Appendix A.

\section{$2.1 \quad$ Investigation Activities}

On July 6 and 7, 1999, corrective action investigation activities were performed as set forth in the CAIP (DOE/NV, 1999). The purpose of the investigation was as follows:

- Identify the presence and concentration of contaminants of potential concern (COPCs) at the CAU.

- Determine the vertical and lateral extent of COPCs.

- Collect sufficient information and analytical data from which corrective action alternatives may be developed and evaluated for the CAU.

- Obtain sufficient sample analytical data for management of investigation-derived waste (IDW).

The investigation activities are summarized below:

- Collected a total of 14 surface and near-surface environmental soil samples from seven sample locations using the direct-push method. These samples were collected from 0 to $1 \mathrm{feet}$ [ft] and 2 to $3 \mathrm{ft}$ below ground surface (bgs) and submitted to an off-site laboratory for the following analyses:

- Total volatile organic compounds (VOCs); total semivolatile organic compounds (SVOCs); total Resource Conservation and Recovery Act (RCRA) metals; total pesticides; total herbicides; total petroleum hydrocarbons (TPH) (gasoline and diesel/oil range), and polychlorinated biphenyls (PCBs). One of the soil samples was also analyzed for isotopic uranium $(\mathrm{U})$, isotopic plutonium $(\mathrm{Pu})$, and gamma-emitting radionuclides.

- Collected one soil sample from 3 to $7 \mathrm{ft}$ bgs for geotechnical analysis. The sample was not submitted for analysis because the results would not benefit closure of the CAU. 
- Collected a total of four surface and near-surface soil samples from two background sample locations. These samples were collected at 0 to $1 \mathrm{ft}$ and 2 to $3 \mathrm{ft}$ bgs and submitted to an off-site laboratory for the following analyses:

- Total RCRA metals, isotopic U, isotopic Pu, strontium (Sr)-90, and gamma spectrometry.

- Soil samples were field screened for VOCs and radiological activity to guide soil sampling activities.

There was no evidence of sludge in the sewage lagoons or swale.

\subsection{Results}

The corrective action investigation analytical results for total VOCs, total SVOCs, total RCRA metals, total pesticides, total herbicides, TPH, PCBs, isotopic U, isotopic $\mathrm{Pu}, \mathrm{Sr}-90$, and gamma-emitting radionuclides were below the preliminary action levels (PALs) outlined in the CAIP (DOE/NV, 1999).

Details of the methods used and results found during the investigation are presented in Appendix A. Based on these results, CAU 232 has been adequately characterized.

\subsection{Need for Corrective Action}

Analytes detected during the corrective action investigation were evaluated against PALs to determine contaminants of concern (COCs) for CAU 232. No constituents were identified above PALs (DOE/NV, 1999); therefore, no corrective actions are necessary for CAU 232.

Best management practice activities were performed by Bechtel Nevada (BN) from December 2 through December 6, 1999 (BN, 1999a and 1999b). The activities included the following:

- Installed a fence and signs to limit access (Figure 2-1).

- Cemented Manhole Number 2 (MH-2) between the sewage lagoons and the swale (Figures 2-2 and 2-3; also depicted in Figure 2-6).

- Cemented the diverter box between Test Cell " $\mathrm{C}$ " and the sewage lagoons (Figures 2-4 and 2-5; also depicted in Figure 2-6). 
Cement was used as the sealing material. It was confirmed during the closure activities that the line that led into the east lagoon from the diverter box had been previously sealed with cement or concrete (BN, 1999a).

Figure 2-6 depicts the current site conditions.

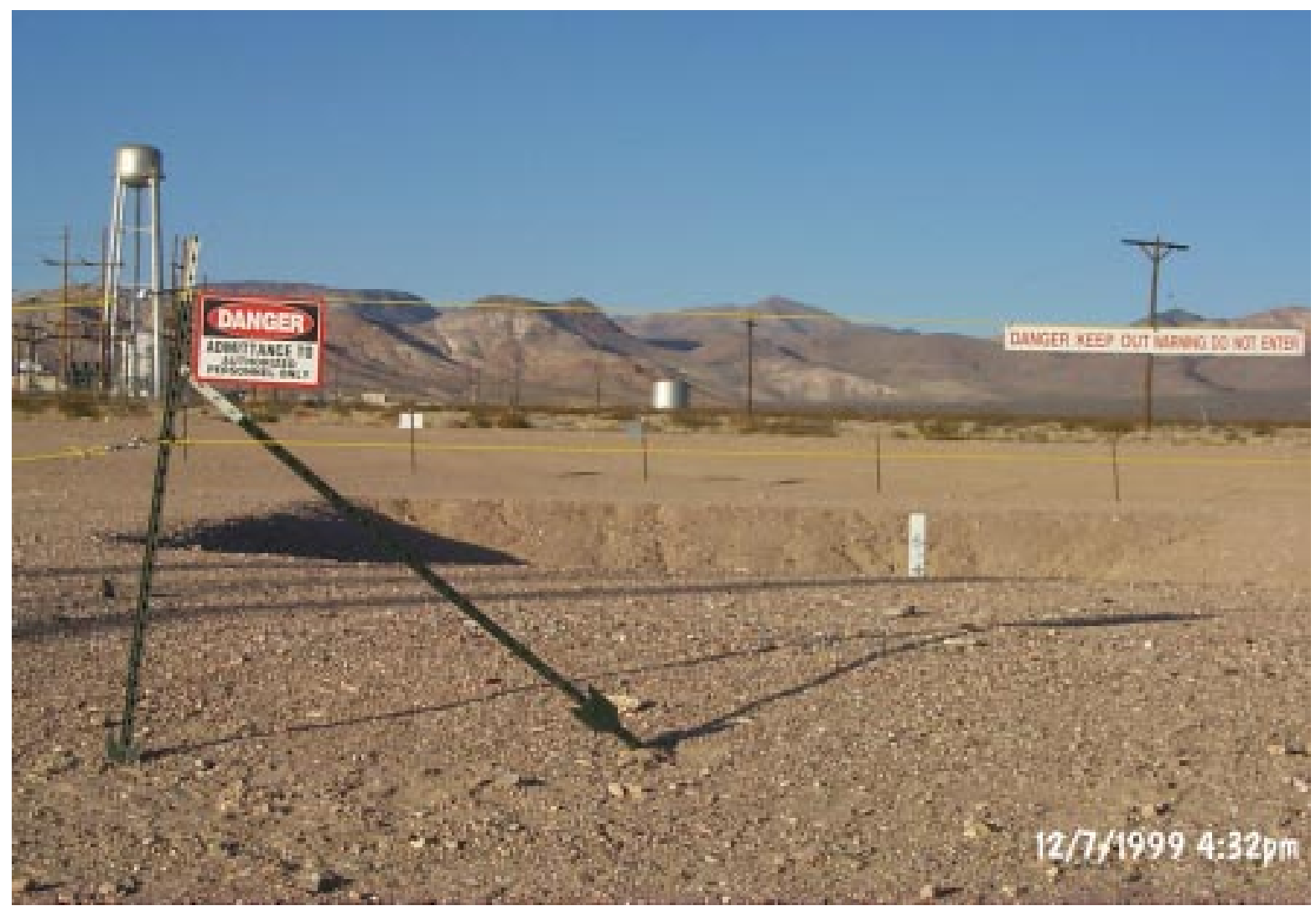

Figure 2-1

Fence and Signs Placed Around Sewage Lagoons Perimeter to Limit Access (BN,1999b) 


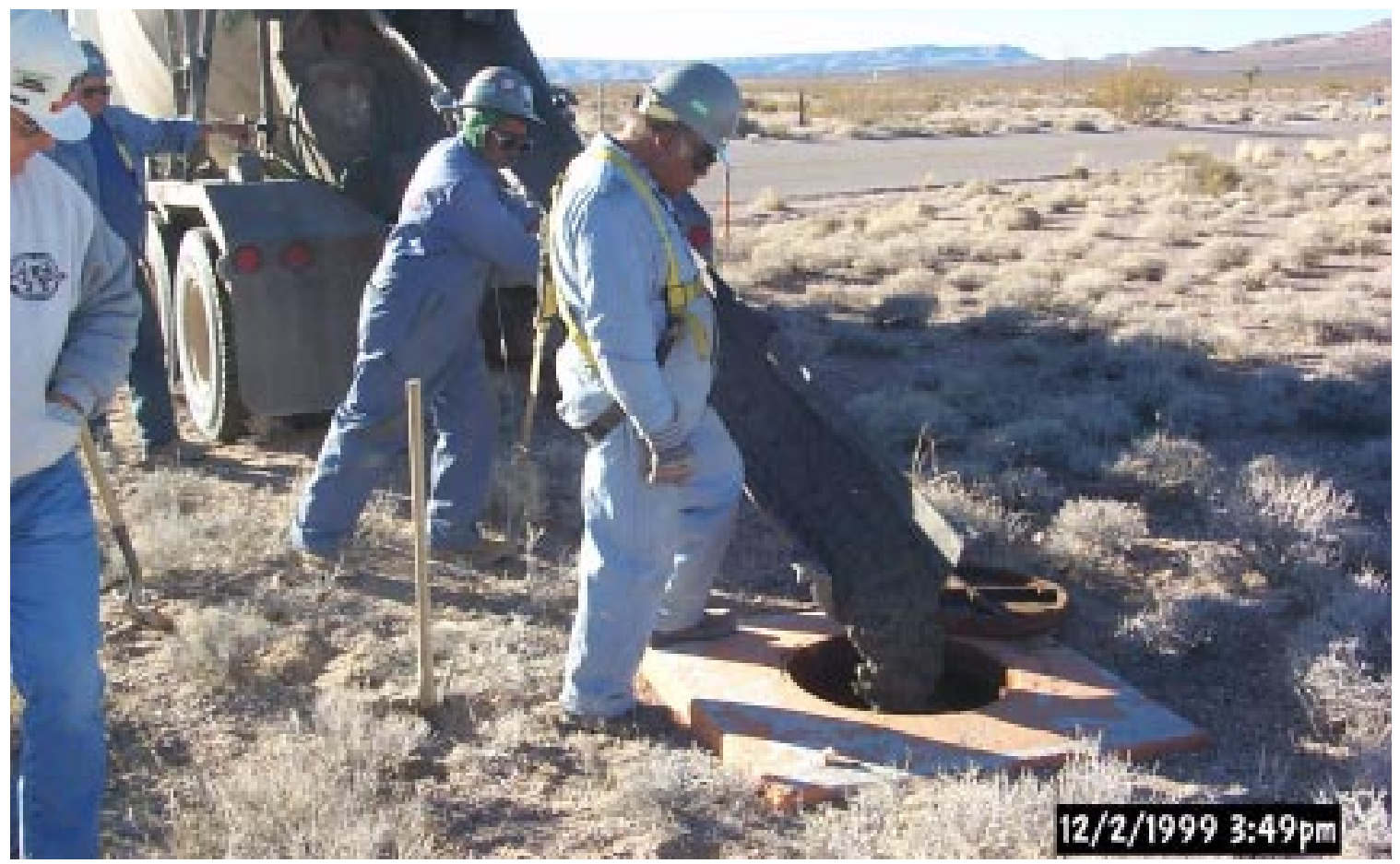

Figure 2-2

Manhole-2 is located between the sewage lagoons inlet to the east and outlet to the swale on the west. The manhole was sealed to prohibit access. (BN,1999b)

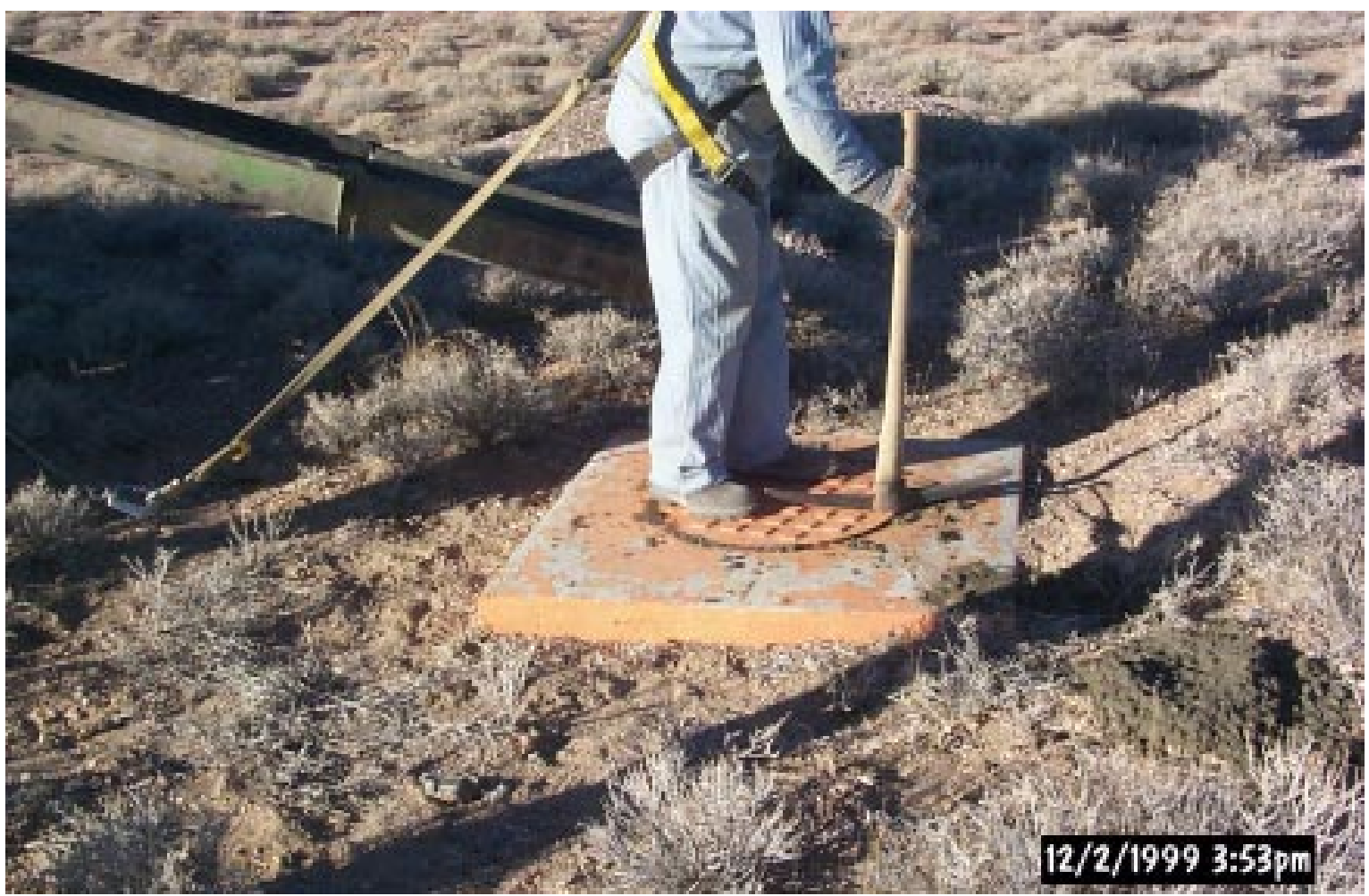

Figure 2-3

Placing Lid on Cemented Manhole-2 (BN, 1999b) 


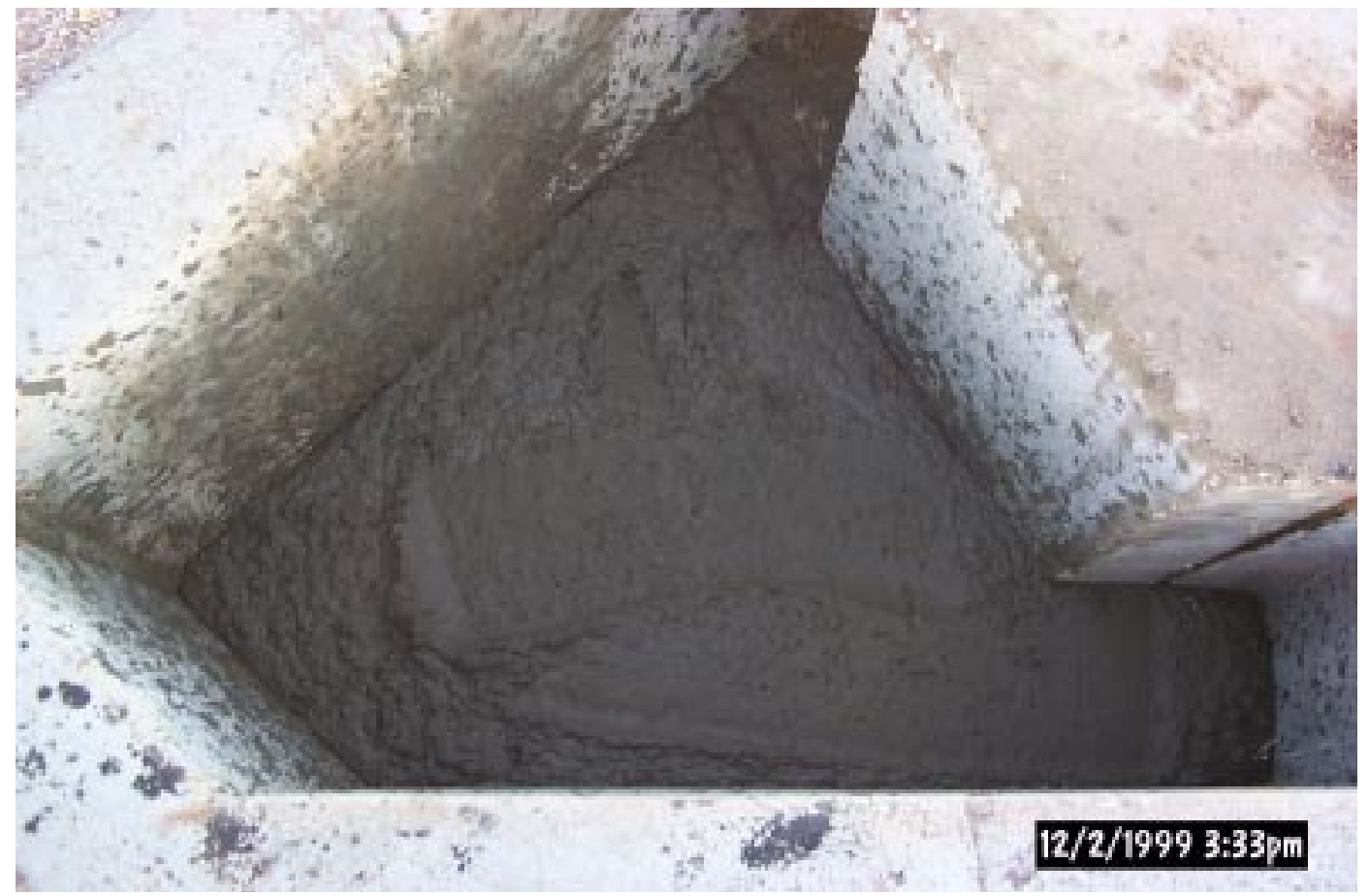

Figure 2-4

Sealing of the Diverter Box Between Test Cell "C" and the Sewage Lagoons (BN, 1999b)

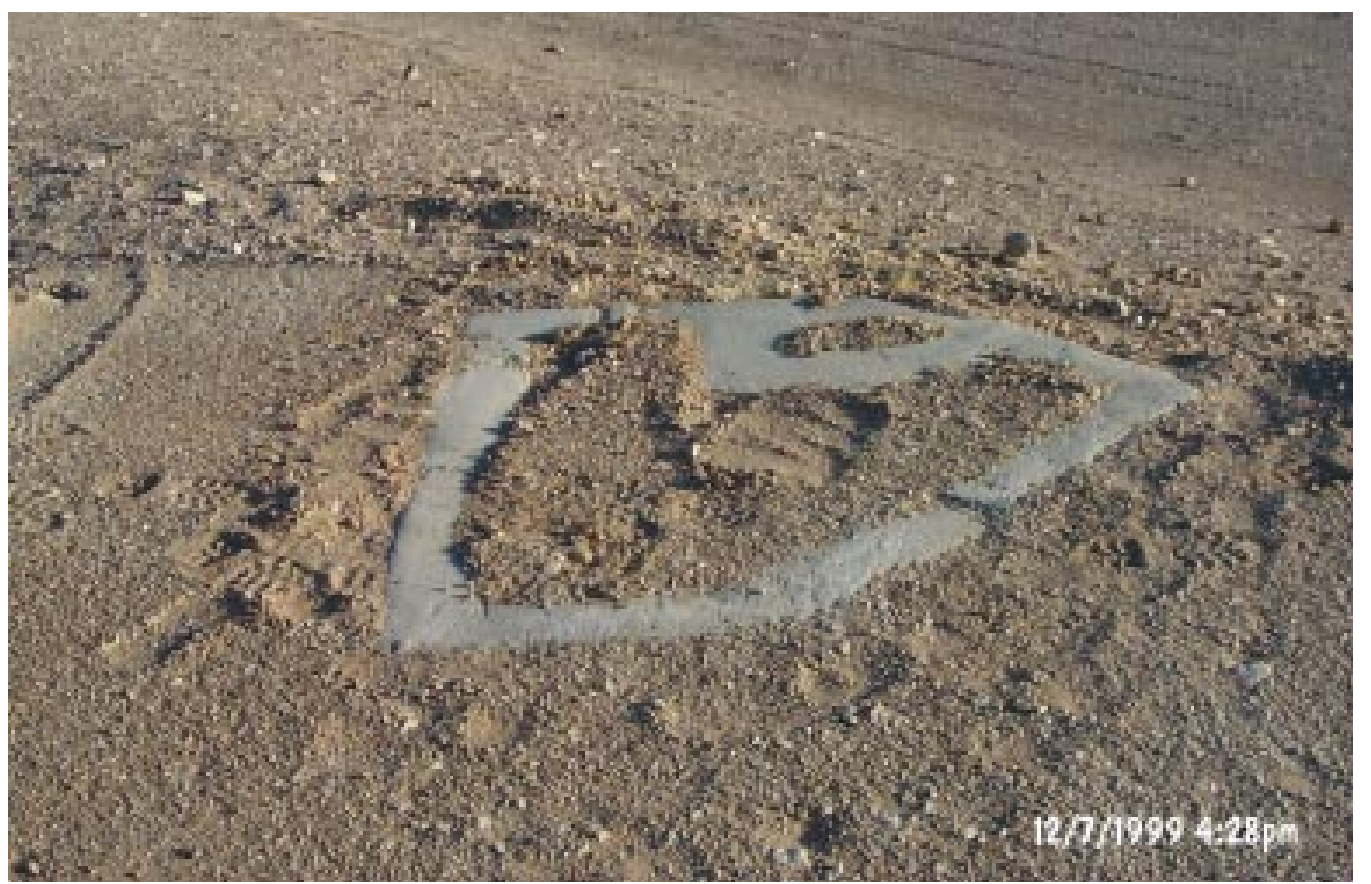

Figure 2-5

Remaining Outline of the Sealed Diverter Box (BN, 1999b) 


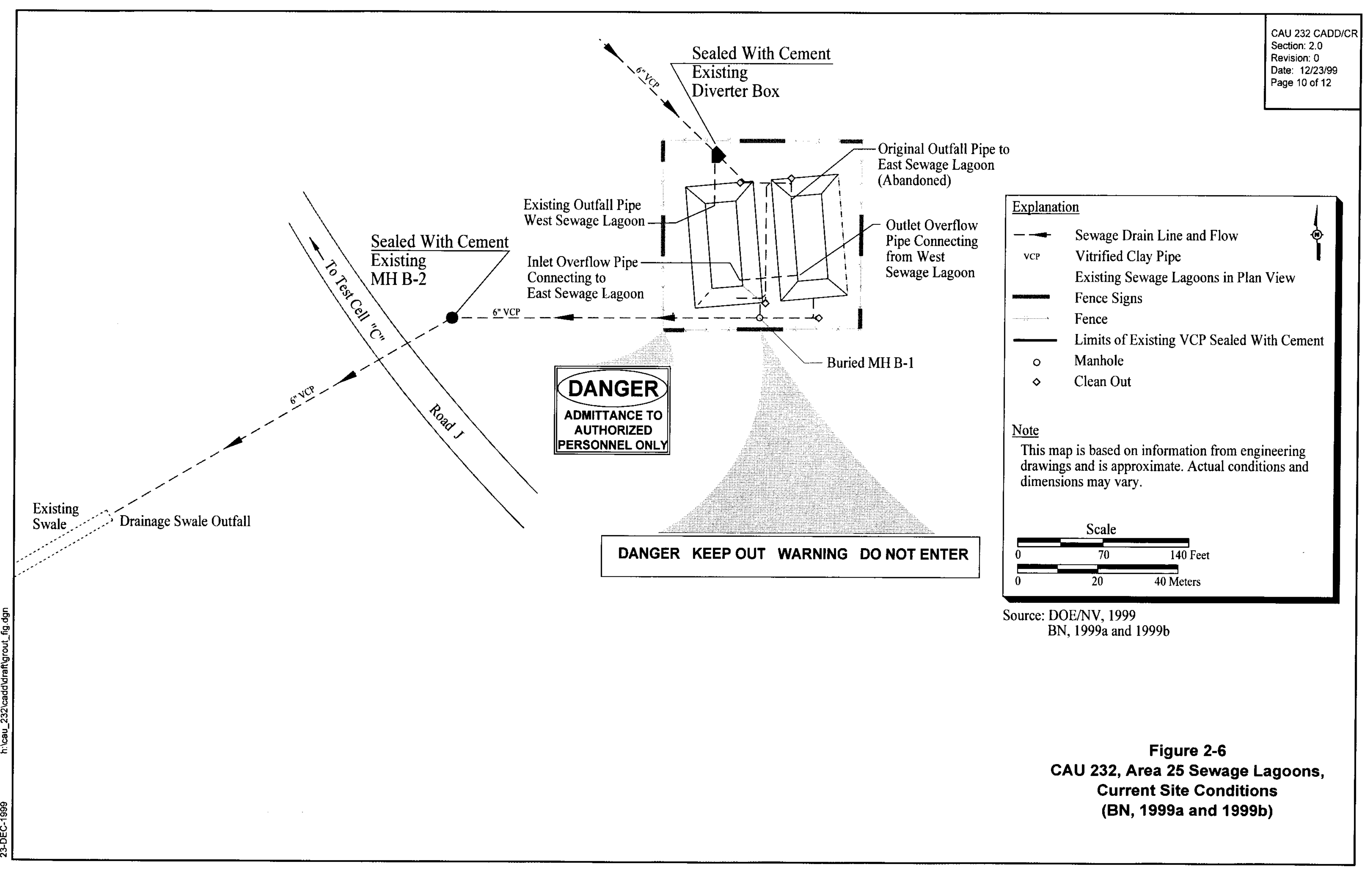




\subsection{Recommendation}

Based on the results of the corrective action investigation discussed in Appendix A, no COCs have been identified at the site. Therefore, DOE/NV recommends the following:

- No further corrective actions be required.

- No Corrective Action Plan be required.

- A Notice of Completion to DOE/NV is requested from the NDEP for the closure of CAU 232 (Area 25 Sewage Lagoons [CAS 25-03-01, Sewage Lagoons]).

- $\quad$ CAU 232 be moved from Appendix III to Appendix IV of the FFACO.

No use restrictions are required to be placed on the CAU. 


\subsection{References}

BN, see Bechtel Nevada.

Bechtel Nevada. 1999a. Letter from David Cowser to J. Appenzeller-Wing (DOE/NV ERD) regarding "Summary of Closure Activities for Corrective Action Unit 232, Area 25 Sewage Lagoon, Nevada Test Site," 16 December. Las Vegas, NV.

Bechtel Nevada. 1999b. Photographs of best management practice activities at CAU 232, Area 25 Sewage Lagoons, 2 to 6 December. Las Vegas, NV.

DOE/NV, see U.S. Department of Energy, Nevada Operations Office.

FFACO, see Federal Facility Agreement and Consent Order.

Federal Facility Agreement and Consent Order. 1996 (as amended). Agreed to by the State of Nevada, the U.S. Department of Energy, and the U.S. Department of Defense.

U.S. Department of Energy, Nevada Operations Office. 1987. Nevada Test Site - Environmental Compliance Atlas. Las Vegas, NV.

U.S. Department of Energy, Nevada Operations Office. 1994. Project Management Plan, Rev. 0. Las Vegas, NV.

U.S. Department of Energy, Nevada Operations Office. 1996a. Final Environmental Impact Statement for the Nevada Test Site and Off-Site Locations in the State of Nevada, DOE/EIS 0243. Las Vegas, NV.

U.S. Department of Energy, Nevada Operations Office. 1996b. Industrial Sites Quality Assurance Project Plan, Nevada Test Site, Nevada, Rev. 1, DOE/NV--372. Las Vegas, NV.

U.S. Department of Energy, Nevada Operations Office. 1999. Corrective Action Investigation Plan for Corrective Action Decision Unit 232: Area 25 Sewage Lagoons, Nevada Test Site, Nevada, Rev. 0, DOE/NV--545. Las Vegas, NV. 


\section{Appendix A}

\section{Corrective Action Investigation Report for CAU 232: Area 25 Sewage Lagoons, Nevada Test Site, Nevada}




\section{A.1.0 Introduction}

This appendix presents corrective action investigation activities and analytical results for the CAU 232, Area 25 Sewage Lagoons at the NTS. Corrective Action Unit 232 includes CAS 25-03-01, Sewage Lagoon (FFACO, 1996). The corrective action investigation was conducted in accordance with the Corrective Action Investigation Plan for Corrective Action Unit 232, Area 25 Sewage Lagoons, Nevada Test Site, Nevada (DOE/NV, 1999) as developed under the FFACO (1996).

Corrective Action Unit 232 was investigated because process knowledge conveyed that sanitary effluent was discharged from various buildings located within Test Cell " $C$ " to the sewage lagoons. Regulated contaminants may have also been discharged to the sewage lagoons. Existing information regarding the concentration and extent of contamination was insufficient to evaluate and select a preferred corrective action for this site without conducting a field investigation. Additional information regarding the history of the site, planning, and the scope of the investigation is presented in the CAIP (DOE/NV, 1999) and will not be repeated in this report.

\section{A.1.1 Project Objectives}

The primary objectives of the investigation were as follows:

- Identify the types and concentrations of COPCs through field and laboratory analytical methods and techniques.

- Determine the vertical and lateral extent of COPCs.

- Provide sufficient information and data to develop appropriate corrective action alternatives for CAU 232.

The selection of soil sample locations for the site was based on site conditions and the strategy developed during the Data Quality Objectives (DQO) process as outlined in the CAIP (DOE/NV, 1999). 


\section{A.1.2 Report Content}

This report contains information and data in sufficient detail to support the recommendation for no further action in the CADD/CR. The contents of this report are as follows:

- Section A.1.0 describes the investigation background, objectives, and the report content.

- Section A.2.0 provides information regarding the field activities and sampling methods.

- Section A.3.0 summarizes the results of the laboratory analyses from the investigation sampling.

- Section A.4.0 discusses the quality assurance (QA) and quality control (QC) procedures that were followed and the results of the QA/QC activities.

- Section A.5.0 is a summary of the investigation results.

- Section A.6.0 provides the cited references.

The complete field documentation and laboratory data, including Field Activity Daily Logs, Sample Collection Logs, Analysis Request/Chain of Custody Forms, laboratory certificates of analyses, analytical results, and surveillance results are retained in the project files. 


\section{A.2.0 Field Investigation and Sampling Activities}

Field investigation and sampling activities were conducted on July 6 and 7, 1999. Soil samples from the surface and near-surface were collected from both sewage lagoons and the swale using the direct-push method. Background samples were collected from undisturbed locations near the CAU. Soil and water samples were collected for QC. Soil samples were field screened for VOCs and radiological activity to guide soil sampling activities. Field-screening levels (FSLs) were not exceeded. All environmental and QC samples were submitted for off-site laboratory analyses. At the conclusion of the field investigation, sample locations were backfilled with soil remaining from sampling activities and surveyed using a Global Positioning System.

The field investigation and sampling program was managed in accordance with the requirements set forth in the CAIP (DOE/NV, 1999). The field activities were performed in accordance with an approved Site-specific Health and Safety Plan (SSHASP) (IT, 1999). The samples were collected and documented by following approved protocols and procedures for sample collection, field activity documentation, decontamination, chain of custody preparation, shipping, and conducting radiation surveys as indicated in the CAIP (DOE/NV, 1999). Quality control samples (e.g., field blanks, equipment rinsate blanks, trip blanks, and sample duplicates) were collected as required by the Industrial Sites QAPP (DOE/NV, 1996) and approved procedures. During field activities, waste minimization practices were followed according to approved procedures, including segregation of the waste by waste stream.

\section{A.2.1 Site Descriptions and Conditions}

Corrective Action Unit 232 is located in the southwest part of the NTS (see Figure 1-1 of the $\mathrm{CADD} / \mathrm{CR}$ ) and includes two sewage lagoons and an outfall swale. The sewage lagoons are located approximately $0.3 \mathrm{mi}$ south of Test Cell "C". The approximate outside dimensions for the west and east sewage lagoons are 100 by $60 \mathrm{ft}$ and 100 by $50 \mathrm{ft}$, respectively. Each lagoon is about $5 \mathrm{ft}$ deep. The sewage lagoons are separated by approximately $15 \mathrm{ft}$. The outfall swale is located about $500 \mathrm{ft}$ southwest of the lagoons. (DOE/NV, 1999)

There is currently no evidence of sludge in the sewage lagoons or swale. 
The sewage lagoons were in operation under the Water Pollution Control General Permit effective February 1, 1994 (NDEP, 1994) and removed in Revision 3 of the permit in 1997 (NDEP, 1997). The site is not listed on the current permit, effective November 13, 1999 (NDEP, 1999).

During the investigation, the weather conditions at the site were dry and hot. Elevated temperatures resulted in the implementation of a work/rest regimen as required by the SSHASP (IT, 1999). Sampling activities and the field investigation schedule were modified to avoid resultant impacts.

\section{A.2.2 Sampling Logistics}

This section describes sample collection and investigation activities for CAU 232.

\section{A.2.2.1 Sample Locations}

The sampling locations were selected based on preliminary analytical results, visual observation (e.g., ponding), and process knowledge. The sample locations are shown in Figure A.2-1.

\section{A.2.2.2 Direct-push Sampling}

A direct-push method (Geoprobe ${ }^{\circledR}$ ) was used to collect samples at the site from 0 to $1 \mathrm{ft}$ and 2 to $3 \mathrm{ft}$ bgs. Soil samples were collected using a Macrocore ${ }^{\circledR}$ sampler with a 2-inch (in.) outside diameter and polyvinyl chloride (PVC) liners. The core liner was field screened for radiological activity. The VOC aliquot was collected immediately afterwards and placed into a jar and sealed. The sample for VOC headspace field screening and the aliquot for TPH (gasoline) was then collected. Remaining soil was homogenized and aliquots were collected for total SVOCs, total RCRA metals, TPH (diesel/oil), isotopic $\mathrm{U}$, isotopic $\mathrm{Pu}, \mathrm{Sr}-90$, and gamma-emitting radionuclides. Final aliquots were collected for PCBs, pesticides, and herbicides. Multiple direct pushes were conducted to collect a sufficient volume of soil as needed.

\section{A.2.2.3 Field Screening}

Field screening and surveys were performed as specified in the CAIP (DOE/NV, 1999). The screening and survey methods were as follows:

- Radiological survey for alpha and beta activity using an Electra instrument 


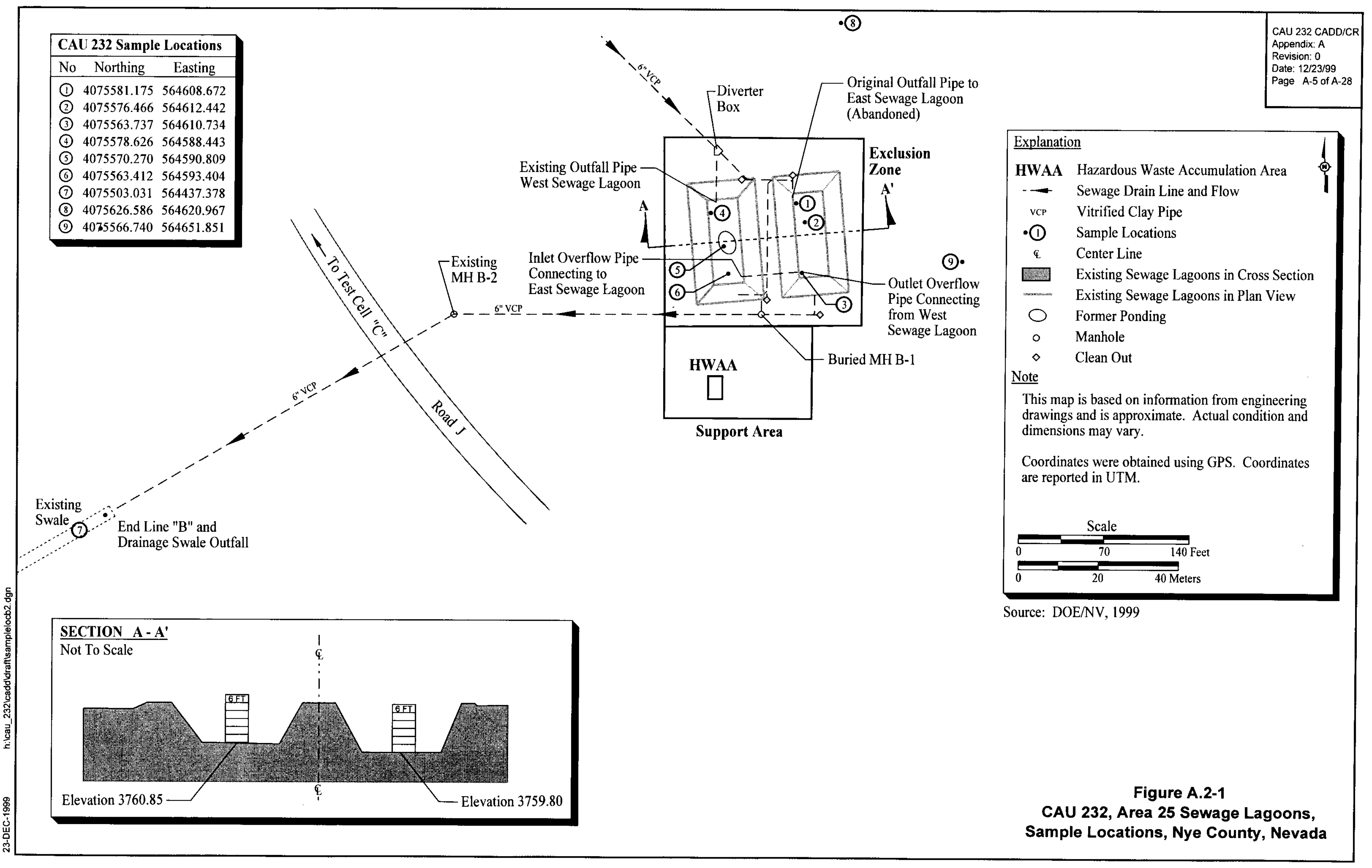


- Radiological survey for gamma activity using a sodium iodide detector

- Headspace screening for VOCs using a photoionization detector

Field-screening levels were used to guide sample collection both laterally and vertically and to provide a basis for the collection of additional environmental samples. The FSLs for VOCs were 20 parts per million (ppm) or 2.5 times background, whichever was higher. The FSLs for radiological surveys were established as the mean background activity level plus 2 times the standard deviation of 20 background sample readings (DOE/NV, 1999).

\section{A.2.2.4 Environmental Samples}

Sample collection was performed as specified in the CAIP (DOE/NV, 1999). The samples collected and submitted for off-site laboratory analyses are identified in Table A.3-1.

A total of 14 environmental soil samples were collected from 7 locations (Figure A.2-1) using the direct-push method. These samples were collected from 0 to $1 \mathrm{ft}$ and 2 to $3 \mathrm{ft}$ bgs and submitted to an off-site laboratory for the following analyses:

- Total VOCs; total SVOCs; total RCRA metals; total pesticides; total herbicides; TPH (gasoline and diesel/oil range), and PCBs. One of the soil samples was also analyzed for isotopic $\mathrm{U}$, isotopic $\mathrm{Pu}$, and gamma-emitting radionuclides.

The field-screening results for VOCs and radiological activity were less than the FSLs; therefore, no further sampling was conducted. A soil sample was collected from 3 to $7 \mathrm{ft} \mathrm{bgs} \mathrm{and} \mathrm{archived} \mathrm{for}$ geotechnical testing pending analytical results.

\section{A.2.2.5 Background Samples}

A total of four surface and near-surface soil samples were collected from two background sample locations. These samples were collected at 0 to $1 \mathrm{ft}$ and 2 to $3 \mathrm{ft}$ bgs and submitted to an off-site laboratory for analysis for total RCRA metals, isotopic U, isotopic $\mathrm{Pu}, \mathrm{Sr}-90$, and gamma-emitting radionuclides. 


\section{A.2.2.6 Quality Control Samples}

A total of nine QC samples were collected and submitted to an off-site laboratory for analyses as follows:

- Three trip blanks were analyzed for total VOCs.

- One field blank, two source blanks, and one equipment blank were analyzed for total VOCs; total SVOCs; total RCRA metals; total pesticides; total herbicides; TPH (gasoline and diesel/oil range), $\mathrm{PCBs}$, isotopic $\mathrm{U}$, isotopic $\mathrm{Pu}$, gamma-emitting radionuclides, and Sr-90.

- One field duplicate and one matrix spike/matrix spike duplicate (MS/MSD) were analyzed for total VOCs; total SVOCs; total RCRA metals; total pesticides; total herbicides; TPH (gasoline and diesel/oil range), $\mathrm{PCBs}$, isotopic $\mathrm{U}$, isotopic $\mathrm{Pu}$, and gamma-emitting radionuclides.

\section{A.2.3 Geology}

The soil at the sewage lagoons is fine-grain sand with gravel. The soil at the background sample locations and the swale is poorly-sorted with abundant gravel, cobbles, and boulders. General field descriptions were performed by the sampling team for each sample and recorded on Sample Collection Logs. The Sample Collection Logs for this site are retained in the project files.

\section{A.2.4 Hydrology}

Well J-11 is located approximately $3 \mathrm{mi}$ south of Test Cell "C". The depth to groundwater at this well is approximately 1,000 ft bgs. Wells $\mathrm{J}-12$ and $\mathrm{J}-13$ are farther away and derive their water from an aquifer approximately $820 \mathrm{ft}$ bgs (Hale and Westenberg, 1995). The natural drainage near or at the site has been modified by grading activities and berm construction associated with the sewage lagoons. The swale appears to have been excavated to direct discharge of any effluent to a natural drainage area. 


\section{A.3.0 Investigation Results}

The analytical results of samples collected from the CAU 232 field investigation have been compiled and evaluated to determine the presence and/or extent of contamination. The analytical results that are above the minimum reporting limits are summarized in the following subsections.

A total of 26 soil and water samples were submitted to Paragon Analytics, Fort Collins, Colorado, and Datachem Laboratory, Salt Lake City, Utah, for laboratory analyses. A list of the samples collected and analyzed for the investigation are presented in Table A.3-1. The analytical parameters and laboratory analytical methods used for this investigation are documented in the Table A.3-2.

The analytical parameters were selected through the application of site process knowledge according to the U.S. Environmental Protection Agency's (EPA's) Guidance for the Data Quality Objectives Process (EPA, 1994c). Preliminary action levels for off-site laboratory analytical methods were determined during the DQO process and are documented in the CAIP (DOE/NV, 1999). Sampling activities were conducted to confirm or disprove assumptions (i.e., models outlined in CAIP) made in the DQO process (DOE/NV, 1999).

\section{A.3.1 Total Volatile Organic Compound Analytical Results}

Total VOCs were not detected at concentrations above the minimum reporting limits (DOE/NV, 1999).

\section{A.3.2 Total Semivolatile Organic Compound Analytical Results}

Total SVOCs were not detected at concentrations above their minimum reporting limits (DOE/NV, 1999).

\section{A.3.3 Total Petroleum Hydrocarbon Results}

Total petroleum hydrocarbons were not detected in the gasoline or diesel/oil ranges above their minimum reporting limits (DOE/NV, 1999). 
Table A.3-1

CAU 232, Area 25 Sewage Lagoons, Sampling Locations and Analyses

\begin{tabular}{|c|c|c|c|c|c|}
\hline $\begin{array}{l}\text { Sample } \\
\text { Location }\end{array}$ & Sample Number & $\begin{array}{c}\text { Depth Below } \\
\text { Ground Surface (ft) }\end{array}$ & Matrix & Sample Type & Analyses \\
\hline \multicolumn{6}{|c|}{ Background Samples } \\
\hline 8 & CLS00003 & $0-1$ & Soil & Background & Set 2 \\
\hline 8 & CSL00004 & $2-3$ & Soil & Background & Set 2 \\
\hline 9 & CSL00005 & $0-1$ & Soil & Background & Set 2 \\
\hline 9 & CSL00006 & $2-3$ & Soil & Background & Set 2 \\
\hline \multicolumn{6}{|c|}{ Swale } \\
\hline 7 & CSL00007 & $0-1$ & Soil & Environmental & Set 4 \\
\hline 7 & CSL00008 & $2-3$ & Soil & Environmental & Set 4 \\
\hline \multicolumn{6}{|c|}{ Sewage Lagoons } \\
\hline 3 & CSL00012A & $0-1$ & Soil & Environmental & Set 4 \\
\hline 3 & CSL00012B & $2-3$ & Soil & Environmental & Set 4 \\
\hline 2 & CSL00013A & $0-1$ & Soil & Environmental & Set 4 \\
\hline 2 & CSL00013B & $2-3$ & Soil & Environmental & Set 4 \\
\hline 1 & CSL00014A & $0-1$ & Soil & Environmental & Sets $1 \& 4$ \\
\hline 1 & CSL00014B & $2-3$ & Soil & Environmental & Set 4 \\
\hline 4 & CSL00016A & $0-1$ & Soil & $\begin{array}{c}\text { Environmental } \\
\text { (MS/MSD) }\end{array}$ & Sets $1 \& 4$ \\
\hline 4 & CSL00016B & $2-3$ & Soil & Environmental & Set 4 \\
\hline 5 & CSL00017A & $0-1$ & Soil & Environmental & Set 4 \\
\hline 5 & CSL00017B & $2-3$ & Soil & Environmental & Set 4 \\
\hline 6 & CSL00018A & $0-1$ & Soil & Environmental & Set 4 \\
\hline 6 & CSL00018B & $2-3$ & Soil & Environmental & Set 4 \\
\hline 6 & CSL00021 & $3-7$ & Soil & Geotechnical & NA \\
\hline \multicolumn{6}{|c|}{ Quality Control Samples } \\
\hline 1 & CSL00015A & $0-1$ & Soil & $\begin{array}{l}\text { Field Duplicate of } \\
\text { CSL00014A }\end{array}$ & Sets $1 \& 4$ \\
\hline 4 & CSL00016A & $0-1$ & Soil & $\mathrm{MS} / \mathrm{MSD}$ & Sets $1 \& 4$ \\
\hline NA & CSL00001 & $\mathrm{NA}$ & Water & Trip Blank & VOC only \\
\hline NA & CSL00002 & NA & Water & Source Blank & Sets $3 \& 4$ \\
\hline NA & CSL00009 & NA & Water & Source Blank & Sets $3 \& 4$ \\
\hline $\mathrm{NA}$ & CSL00010 & NA & Water & Field Blank & Sets $3 \& 4$ \\
\hline NA & CSL00011 & NA & Water & Trip Blank & VOC only \\
\hline NA & CSL00019 & NA & Water & Trip Blank & VOC only \\
\hline NA & CSL00020 & NA & Water & $\begin{array}{c}\text { Equipment Rinsate } \\
\text { Blank }\end{array}$ & Sets $3 \& 4$ \\
\hline
\end{tabular}

Set 1 - Gamma spectrometry, isotopic Pu, isotopic $U$

Set 2 - Total RCRA metals, gamma spectrometry, isotopic $\mathrm{Pu}$, isotopic $\mathrm{U}$, and $\mathrm{Sr}-90$

Set 3 - Gamma spectrometry, isotopic Pu, isotopic U, and Sr-90

Set 4 - Total VOC, total SVOC, total RCRA metals, total herbicides, TPH (gasoline and diesel/oil range), PCBs, and total pesticides 
Table A.3-2

Laboratory Analytical Methods Used for Samples Collected at CAU 232, Area 25 Sewage Lagoons, Nevada Test Site

\begin{tabular}{|c|c|}
\hline Analytical Parameter & Analytical Method \\
\hline Total volatile organic compounds & EPA $8260 B^{a}$ \\
\hline Total petroleum hydrocarbons - gasoline and diesel/oil & EPA $8015 B(\text { modified })^{a}$ \\
\hline Total semivolatile organic compounds & EPA $8270 C^{a}$ \\
\hline $\begin{array}{l}\text { Total RCRA metals (arsenic, barium, cadmium, chromium, lead, selenium, silver, } \\
\text { and mercury) }\end{array}$ & $\begin{array}{l}\text { EPA } 6010 B / 7470 A^{a} \\
\text { EPA } 6010 B / 7471 A^{a}\end{array}$ \\
\hline Isotopic Uranium & ASTM 3972-97 \\
\hline Isotopic Plutonium & ASTM $3865-97^{\mathrm{C}}$ \\
\hline Gamma Spectrometry & $\begin{array}{l}\text { EPA } 901.1^{d} \\
\text { HASL } 300^{e}\end{array}$ \\
\hline Strontium-90 & ASTM D5811-95 \\
\hline Total Pesticides & EPA $8081 A^{a}$ \\
\hline PCBs & EPA $8082^{a}$ \\
\hline Total Herbicides & EPA $8151 A^{a}$ \\
\hline
\end{tabular}

\footnotetext{
${ }^{a}$ EPA Test Methods for Evaluating Solid Waste, 3rd Edition, Parts 1-4, SW-846 (EPA, 1996)

b Standard Test Method for Isotopic Uranium Water by Radiochemistry (ASTM, 1997a)

Standard Test Method for Plutonium in Water (ASTM, 1997b)

d Prescribed Procedure for Measurements of Radioactivity in Drinking Water (EPA, 1980)

Environmental Measurements Laboratory Procedures Manual (DOE, 1997)

f Standard Test Method for Strontium-90 in Water (ASTM, 1995)
}

\section{A.3.4 Total RCRA Metals Results}

The total RCRA metals detected at concentrations above their minimum reporting limits (DOE/NV, 1999) are presented in Table A.3-3. The RCRA metals cadmium, selenium, mercury, and silver were not detected. The total RCRA metal results were all below the PALs (DOE/NV, 1999; EPA, 1998).

\section{A.3.5 Polychlorinated Biphenyl(s) Results}

No PCBs were detected. 
Table A.3-3

Total RCRA Metals Detected Above Minimum Reporting Limits CAU 232, Area 25 Sewage Lagoons, Nevada Test Site

\begin{tabular}{|c|c|c|c|c|c|c|c|}
\hline \multirow{2}{*}{$\begin{array}{l}\text { Sample } \\
\text { Location }\end{array}$} & \multirow{2}{*}{$\begin{array}{l}\text { Sample } \\
\text { Number }\end{array}$} & \multirow{2}{*}{$\begin{array}{c}\text { Start } \\
\text { Depth } \\
\text { bgs (ft) }\end{array}$} & \multirow{2}{*}{$\begin{array}{c}\text { End } \\
\text { Depth } \\
\text { bgs (ft) }\end{array}$} & \multicolumn{4}{|c|}{ Contaminants of Potential Concern $(\mathrm{mg} / \mathrm{kg})$} \\
\hline & & & & Arsenic & Barium & Chromium & Lead \\
\hline \multicolumn{4}{|c|}{ Industrial Soil PRGa } & 3 & 100,000 & 64 & 1,000 \\
\hline \multicolumn{8}{|c|}{ Background Sample Locations } \\
\hline \multirow[t]{2}{*}{8} & CSL00003 & 0 & 1 & $2.75(J)$ & 110 & $5.6(\mathrm{~J})$ & 6.22 \\
\hline & CSL00004 & 2 & 3 & $2.05(J)$ & 96 & $2.9(\mathrm{~J})$ & 4.42 \\
\hline \multirow[t]{2}{*}{9} & CSL00005 & 0 & 1 & $2.73(\mathrm{~J})$ & 97 & $5.3(\mathrm{~J})$ & 7.45 \\
\hline & CSL00006 & 2 & 3 & $1.88(J)$ & 75 & $2.6(\mathrm{~J})$ & 5.49 \\
\hline \multicolumn{8}{|c|}{ Swale } \\
\hline \multirow[t]{2}{*}{7} & CSL00007 & 0 & 1 & $2.41(\mathrm{~J})$ & 84 & $4.1(\mathrm{~J})$ & 5.51 \\
\hline & CSL00008 & 2 & 3 & $2.06(J)$ & 63 & $2.5(\mathrm{~J})$ & 4.14 \\
\hline \multicolumn{8}{|c|}{ East Sewage Lagoon } \\
\hline \multirow[t]{2}{*}{3} & CSL00012A & 0 & 1 & $2.36(\mathrm{~J})$ & 78 & $2.5(\mathrm{~J})$ & 3.74 \\
\hline & CSL00012B & 2 & 3 & $2.06(\mathrm{~J})$ & 64 & $2.5(\mathrm{~J})$ & 3.99 \\
\hline \multirow[t]{2}{*}{2} & CSL00013A & 0 & 1 & $2.19(\mathrm{~J})$ & 62 & $2.3(\mathrm{~J})$ & 4.29 \\
\hline & CSL00013B & 2 & 3 & $1.87(\mathrm{~J})$ & 100 & $1.3(\mathrm{~J})$ & 3.73 \\
\hline \multirow[t]{3}{*}{1} & CSL00014A & 0 & 1 & $1.66(J)$ & 69 & $2.3(\mathrm{~J})$ & 3.81 \\
\hline & CSL00014B & 2 & 3 & $1.84(\mathrm{~J})$ & 91 & $2.3(\mathrm{~J})$ & 3.23 \\
\hline & CSL00015A & 0 & 1 & $2.14(\mathrm{~J})$ & 78 & $2.3(\mathrm{~J})$ & 4.94 \\
\hline \multicolumn{8}{|c|}{ West Sewage Lagoon } \\
\hline \multirow[t]{2}{*}{4} & CSL00016A & 0 & 1 & $2.06(J)$ & 88 & $3.2(\mathrm{~J})$ & 5.14 \\
\hline & CSL00016B & 2 & 3 & $1.86(\mathrm{~J})$ & 68 & $2.8(\mathrm{~J})$ & 4.16 \\
\hline \multirow[t]{2}{*}{5} & CSL00017A & 0 & 1 & $2.36(\mathrm{~J})$ & 110 & $3.2(\mathrm{~J})$ & 6.00 \\
\hline & CSL00017B & 2 & 3 & $1.83(\mathrm{~J})$ & 75 & $1.4(\mathrm{~J})$ & 3.05 \\
\hline \multirow[t]{2}{*}{6} & CSL00018A & 0 & 1 & $2.25(\mathrm{~J})$ & 97 & $3.9(\mathrm{~J})$ & 5.51 \\
\hline & CSL00018B & 2 & 3 & $1.68(\mathrm{~J})$ & 93 & $1.7(\mathrm{~J})$ & 3.14 \\
\hline
\end{tabular}

${ }^{\text {a} E P A ~ R e g i o n ~} 9$ Preliminary Remediation Goals (EPA, 1998) $\mathrm{J}=$ Estimated

$\mathrm{mg} / \mathrm{kg}=$ Milligram(s) per kilogram

$\mathrm{ft}=$ Feet

bgs $=$ Below ground surface 


\section{A.3.6 Total Pesticides Results}

Total pesticides were not detected at concentrations above their minimum reporting limits (DOE/NV, 1999).

\section{A.3.7 Total Herbicides Results}

Total herbicides were not detected.

\section{A.3.8 Isotopic Uranium Results}

Uranium-234 and U-238 were detected at concentrations above the minimum reporting limit (DOE/NV, 1999). The analytical results are presented in Table A.3-4. The U-234 and U-238 concentrations are not distinguishable from their naturally occurring concentrations at background locations (McArthur and Miller, 1989; U.S. Ecology and Atlan-Tech, 1992); therefore, are below the PALs.

\section{A.3.9 Isotopic Plutonium Results}

Isotopic Pu was not detected.

\section{A.3.10 Strontium-90 Results}

The concentration of Sr-90 in the soil samples was not detected above the minimum reporting limits (DOE/NV, 1999).

\section{A.3.11 Gamma Spectrometry Results}

The radionuclides detected in soil using gamma spectrometry were actinium-228, bismuth-214, potassium-40, lead-212, lead-214, and thallium-208. Results are provided in Table A.3-5. The radionuclides detected occur naturally and are found in soil throughout Nevada. The radionuclide concentrations are not distinguishable from their naturally occurring concentrations found at background locations (McArthur and Miller, 1989; U.S Ecology and Atlan-Tech, 1992); therefore, are below the PALs. 
Table A.3-4

Isotopic Uranium Results for CAU 232, Area 25 Sewage Lagoons, Nevada Test Site

\begin{tabular}{|c|c|c|c|c|c|c|}
\hline \multirow{2}{*}{$\begin{array}{l}\text { Sample } \\
\text { Location }\end{array}$} & \multirow{2}{*}{$\begin{array}{l}\text { Sample } \\
\text { Number }\end{array}$} & \multirow{2}{*}{$\begin{array}{l}\text { Start Depth } \\
\text { bgs (ft) }\end{array}$} & \multirow{2}{*}{$\begin{array}{l}\text { End Depth } \\
\text { bgs (ft) }\end{array}$} & \multicolumn{3}{|c|}{$\begin{array}{l}\text { Contaminants of Potential Concern } \\
\qquad(\mathrm{pCi} / \mathrm{g})\end{array}$} \\
\hline & & & & Uranium-234 & Uranium-235 & Uranium-238 \\
\hline \multicolumn{4}{|c|}{ Range of Background Concentrations } & $0.1-2.6^{a}$ & $0.05-0.1^{\mathrm{a}}$ & $0.21-3.2^{b}$ \\
\hline \multicolumn{7}{|c|}{ Background Sample Locations } \\
\hline 8 & CSL00003 & 0 & 1 & $0.77 \pm 0.14$ & -- & $0.62 \pm 0.12$ \\
\hline 8 & CSL00004 & 2 & 3 & $0.92 \pm 0.16$ & -- & $0.83 \pm 0.15$ \\
\hline 9 & CSL00005 & 0 & 1 & $0.68 \pm 0.13$ & $0.105 \pm 0.043(B)$ & $0.75 \pm 0.14$ \\
\hline 9 & CSL00006 & 2 & 3 & $0.81 \pm 0.15$ & -- & $0.85 \pm 0.16$ \\
\hline \multicolumn{7}{|c|}{ East Sewage Lagoon } \\
\hline \multirow[t]{2}{*}{1} & CSL00014A & 0 & 1 & $1.14 \pm 0.19$ & $0.084 \pm 0.039(B)$ & $1.00 \pm 0.17$ \\
\hline & CSL00015A & 0 & 1 & $0.89 \pm 0.15$ & -- & $0.81 \pm 0.14$ \\
\hline \multicolumn{7}{|c|}{ West Sewage Lagoon } \\
\hline 4 & CSL00016A & 0 & 1 & $0.94 \pm 0.17$ & -- & $1.01 \pm 0.17$ \\
\hline
\end{tabular}

aBackground concentration listed in the Environmental Monitoring Report for the Proposed Ward Valley California Low-Level Radioactive (LLRW) Facility (U.S. Ecology and Atlan-Tech, 1992).

${ }^{b}$ Background concentration listed in or derived from Off-Site Radiation Exposure Review Project,

Phase II Soils Program (McArthur and Miller, 1989).

$\mathrm{B}=$ Analyte concentration is greater than the minimum detectable concentrations.

$--=$ Not detected above minimum reporting limits

$\mathrm{pCi} / \mathrm{g}=$ Picocurie $(\mathrm{s})$ per gram

$\mathrm{ft}=$ Feet

bgs $=$ Below ground surface 
Table A.3-5

Gamma Spectrometry Results for

CAU 232, Area 25 Sewage Lagoons, Nevada Test Site

\begin{tabular}{|c|c|c|c|c|c|c|c|c|c|}
\hline \multirow{2}{*}{$\begin{array}{l}\text { Sample } \\
\text { Location }\end{array}$} & \multirow{2}{*}{$\begin{array}{l}\text { Sample } \\
\text { Number }\end{array}$} & \multirow{2}{*}{$\begin{array}{c}\text { Start } \\
\text { Depth } \\
\text { bgs (ft) }\end{array}$} & \multirow{2}{*}{$\begin{array}{c}\text { End } \\
\text { Depth } \\
\text { bgs (ft) }\end{array}$} & \multicolumn{6}{|c|}{ Contaminants of Potential Concern $(\mathrm{pCi} / \mathrm{g})$} \\
\hline & & & & Actinium-228 & Bismuth-214 & Potassium-40 & Lead-212 & Lead-214 & Thallium-208 \\
\hline \multicolumn{4}{|c|}{ Range of Background Samples } & $<0.4-3.64^{\mathrm{a}}$ & $<0.1-3.47^{a}$ & $11.0-96^{a}$ & $0.86-2.9^{a}$ & $0.5-2.9^{b^{*}}$ & $0.5-3.4^{\mathrm{a}}$ \\
\hline \multicolumn{10}{|c|}{ Background Sample Locations } \\
\hline \multirow[t]{2}{*}{8} & CSL00003 & 0 & 1 & $1.45 \pm 0.40(\mathrm{~J})$ & $0.58 \pm 0.25(J)$ & $27.6 \pm 5.4(\mathrm{~J})$ & $1.30 \pm 0.28(\mathrm{~J})$ & $0.76 \pm 0.22(\mathrm{~J})$ & $0.53 \pm 0.16(\mathrm{~J})$ \\
\hline & CSL00004 & 2 & 3 & $1.63 \pm 0.41(\mathrm{~J})$ & $0.89 \pm 0.26(J)$ & $28.1 \pm 5.4(\mathrm{~J})$ & $1.58 \pm 0.31(\mathrm{~J})$ & $0.87 \pm 0.22(\mathrm{~J})$ & $0.49 \pm 0.14(\mathrm{~J})$ \\
\hline \multirow[t]{2}{*}{9} & CSL00005 & 0 & 1 & $1.35 \pm 0.39(\mathrm{~J})$ & $0.58 \pm 0.26(J)$ & $24.9 \pm 4.9(\mathrm{~J})$ & $1.44 \pm 0.30(\mathrm{~J})$ & $0.73 \pm 0.21(\mathrm{~J})$ & $0.45 \pm 0.15(\mathrm{~J})$ \\
\hline & CSL00006 & 2 & 3 & $1.77 \pm 0.43(\mathrm{~J})$ & $0.86 \pm 0.26(\mathrm{~J})$ & $29.0 \pm 5.6(\mathrm{~J})$ & $1.49 \pm 0.30(\mathrm{~J})$ & $0.74 \pm 0.20(\mathrm{~J})$ & $0.53 \pm 0.14(\mathrm{~J})$ \\
\hline \multicolumn{10}{|c|}{ East Sewage Lagoon } \\
\hline \multirow[t]{2}{*}{1} & CSL00014A & 0 & 1 & $1.28 \pm 0.37(\mathrm{~J})$ & $0.86 \pm 0.26(J)$ & $27.1 \pm 5.3(\mathrm{~J})$ & $1.23 \pm 0.27(\mathrm{~J})$ & $0.78 \pm 0.21(\mathrm{~J})$ & $0.36 \pm 0.13(\mathrm{~J})$ \\
\hline & CSL00015A & 0 & 1 & $1.27 \pm 0.39(\mathrm{~J})$ & $0.83 \pm 0.30(\mathrm{~J})$ & $29.4 \pm 5.8(J)$ & $1.36 \pm 0.30(\mathrm{~J})$ & $0.67 \pm 0.21(\mathrm{~J})$ & $0.46 \pm 0.15(\mathrm{~J})$ \\
\hline \multicolumn{10}{|c|}{ West Sewage Lagoon } \\
\hline 4 & CSL00016A & 0 & 1 & $1.27 \pm 0.37(\mathrm{~J})$ & $0.74 \pm 0.23(\mathrm{~J})$ & $28.7 \pm 5.5(\mathrm{~J})$ & $1.47 \pm 0.30(\mathrm{~J})$ & $0.73 \pm 0.21(\mathrm{~J})$ & -- \\
\hline
\end{tabular}

aBackground concentration listed in Environmental Monitoring Report for the Proposed Ward Valley California Low-Level Radioactive Waste (LLRW) Facility (U.S. Ecology \& Atlan-Tech, 1992).

bBackground concentration listed in or derived from Off-Site Radiation Exposure Review Project, Phase II Soils Program

(McArthur and Miller, 1989). *Note: Soil concentrations are calculated values derived from the U-238, Th-232, and

Pu-239/240 concentrations reported in McArthur and Miller (1989).

$J=$ Estimated

-- = Not detected above minimum reporting limits.

$\mathrm{pCi} / \mathrm{g}=$ Picocurie(s) per gram

$\mathrm{ft}=$ Feet

bgs $=$ Below ground surface 


\section{A.4.0 Quality Assurance}

The results of the QA/QC activities for the Area 25 Sewage Lagoons corrective action investigation sampling events are summarized in the following text. Detailed information regarding the QA program is contained in the Industrial Sites QAPP (DOE/NV, 1996).

Quality control results are typically judged in terms of precision, accuracy, representativeness, completeness, and comparability and are described in the following sections.

\section{A.4.1 Precision}

Precision is a quantitative measure of the variability of a group of measurements from their average value. Precision is assessed for inorganic analysis by collecting and analyzing duplicate field samples and comparing the results with the original sample. Precision is also assessed by creating, preparing, analyzing, and comparing laboratory duplicates from one or more field samples in inorganic analyses and MS/MSD samples for organic analyses. Precision is reported as relative percent difference (RPD) which is calculated as the difference between the measured concentrations of duplicate samples, divided by the average of the two concentrations, and multiplied by 100. Any deviation from these requirements has been documented and explained and the related data qualified accordingly. The qualification process is described in Section A.4.7.1.

\section{A.4.2 Accuracy}

Analytical accuracy is defined as the nearness of a measurement to the true or accepted reference value. It is the composite of the random and systematic components of the measurement system and measures bias in the measurement system. The random component of accuracy is measured and documented through the analyses of spiked samples. Sampling accuracy is assessed by evaluating the results of spiked samples and laboratory control samples. Accuracy measurements are calculated as percent recovery by dividing the measured sample concentration by the true concentration and multiplying the quotient by 100 .

Field accuracy is assessed by confirming that the documents of record track the sample from its origin, through transfer of custody, to disposal. The goal of field accuracy is for all samples to be 
collected from the correct locations at the correct time, placed in a correctly labeled container with the correct preservative, and sealed with custody tape to prevent tampering. All samples in this sampling event were properly collected and forwarded to the laboratories as described above.

\section{A.4.3 Representativeness}

Representativeness expresses the degree to which sample data accurately and precisely represent a characteristic of a population, parameter variations at a sampling point, or an environmental condition (EPA, 1987). Sample representativeness was achieved through the implementation of a sampling program designed to ensure proper sampling locations, number of samples, and the use of validated analytical methods. Representativeness was assessed through analysis of duplicate samples. Representativeness of the samples taken in this sampling event was assured by collecting the specified number of samples (DOE/NV, 1999) and by analyzing them by the approved analytical methods shown in Table A.3-2.

\section{A.4.4 Completeness}

Completeness is defined as the percentage of measurements made that are judged to be valid. A sampling and analytical requirement of 80 percent completeness was established for this project (DOE/NV, 1996). All sample results were judged to be valid; therefore, representing 100 percent completeness.

The specified sampling locations were utilized as planned. All samples were collected as specified in the CAIP (DOE/NV, 1999), and all sample containers reached the laboratory intact and properly preserved (when applicable). Sample temperatures were maintained during shipment to the laboratory, and sample chain of custody was maintained during sample storage and/or shipment.

\section{A.4.5 Comparability}

Comparability is a qualitative parameter expressing the confidence with which one dataset can be compared to another (EPA, 1987). To ensure comparability, the CAU 232 field and sampling activities were performed and documented in accordance with approved standard procedures, and all samples were collected in accordance with the CAIP (DOE/NV, 1999). Approved standardized methods and procedures were also used to analyze and report the data (e.g., Contract Laboratory 
Program [CLP] and/or CLP-like data packages). This approach ensures that the data from this project can be compared to other datasets. Based on the minimum comparability requirements specified in the Industrial Sites QAPP (DOE/NV, 1996), all requirements were met.

Field (i.e., sample-handling) documentation, laboratory nonconformance reports, and the precision and accuracy of quality-control sample results were evaluated for their effect on the results of the associated environmental soil samples. The environmental sample results were then qualified according to processes outlined in the following sections. Documentation of the data qualifications resulting from these reviews is retained in the project files.

\section{A.4.6 Tier I and Tier II Data Evaluations}

All laboratory data from samples collected at CAU 232 have been evaluated for data quality according to the EPA Functional Guidelines (EPA, 1994a and 1994b). These guidelines are implemented in a tiered process and are presented in the following text. There were no data rejected for this project. Only valid data, whether estimated (i.e., J-qualified) or not, were used.

The changes resulting from the data evaluation process were documented in the project files and were summarized in memoranda for each sample delivery group (SDG). These memoranda are maintained in the project files.

\section{A.4.6.1 Tier I Evaluation}

Tier I evaluation for both chemical and radiological analyses examines (but is not limited to):

- Sample count/type consistent with chain of custody

- Analysis count/type consistent with chain of custody

- Correct sample matrix

- Significant problems stated in cover letter or case narrative

- Completeness of certificates of analysis

- Completeness of CLP or CLP-like packages

- Completeness of signatures, dates, and times on chain of custody

- Condition-upon-receipt variance form included

- Requested analyses performed on all samples

- Date received/analyzed given for each sample

- Correct concentration units indicated

- Electronic data transfer supplied 
- Results reported for field and laboratory QC samples

- Whether or not the deliverable met the overall objectives of the project

\section{A.4.6.2 Tier II Evaluation}

Tier II evaluation for both chemical and radiological analyses examines (but is not limited to):

\section{Chemical:}

- Correct detection limits achieved

- Holding time criteria met

- QC batch association for each sample

- Cooler temperature upon receipt

- Sample $\mathrm{pH}$ for aqueous samples, as required

- Detection limits properly adjusted for dilution, as required

- Blank contamination evaluated and applied to sample results/qualifiers

- $\quad$ MS/MSD percent recoveries (\%R) and RPDs evaluated and applied to laboratory results/qualifiers

- Field duplicate RPDs evaluated using professional judgement and applied to laboratory results/qualifiers

- Laboratory duplicate RPDs evaluated and applied to laboratory results/qualifiers

- $\quad$ Surrogate $\% \mathrm{R}$ evaluated and applied to laboratory results/qualifiers

- Laboratory control sample $\% \mathrm{R}$ evaluated and applied to laboratory results/qualifiers

- Initial and continuing calibration evaluated and applied to laboratory results/qualifiers

- Internal standard evaluated and applied to laboratory results/qualifiers

- Recalculation of 10 percent of laboratory results from raw data

\section{Radioanalytical:}

- Correct detection limits achieved

- Blank contamination evaluated and applied to sample results/qualifiers

- Certificate of Analysis consistent with data package documentation

- Quality control sample results (duplicates, laboratory control samples, MS/MSD) evaluated and applied to laboratory result qualifiers 
- Sample results, error, and minimum detectable activity evaluated and applied to laboratory result qualifiers

- Detector system calibrated to National Institute for Standards and Technology (NIST)traceable sources

- Calibration sources preparation was documented, demonstrating proper preparation and appropriateness for sample matrix, emission energies, and concentrations

- Detector system response to daily, weekly, and monthly background and calibration checks for peak energy, peak centroid, peak full-width half-maximum, and peak efficiency

- Tracers NIST-traceable, appropriate for the analysis performed, and recoveries that met QC requirements

- Documentation of all QC sample preparation complete and properly performed

- Spectra lines, emissions, particle energies, peak areas, and background peak areas support the identified radionuclide and its concentration

\section{A.4.6.3 Tier III}

Data quality considerations that are included in EPA data review functional guidelines (EPA, 1994a and 1994b) as a Tier III review include the additional evaluations:

\section{Chemical:}

- Mass spectrometer tuning criteria

- Initial and continuing calibration verification

- Internal standard evaluation

- Organic compound quantitation

- Inductively coupled plasma (ICP) interference check sample evaluation

- Graphite furnace atomic absorption quality control

- ICP serial dilution effects

- Recalculation of all laboratory results from raw data

\section{Radioanalytical:}

- QC sample results (e.g., calibration source concentration, percent recovery, and RPD) verified

- Radionuclides and their concentration appropriate considering their decay schemes, half-lives, and process knowledge and history of the facility and site

- Each identified line in spectra verified against emission libraries and calibration results

- Independent identification of spectra lines, area under the peaks, and quantification of radionuclide concentration in a random number of sample results 
A Tier III review of at least 5 percent of the sample analytical data was performed by Techlaw, Inc. in Lakewood, Colorado. No modifications were made to the sample analytical data as a result of the Tier III Review.

\section{A.4.7 Quality Control Samples}

There were three trip blanks, one field blank, one equipment rinsate blank, two source blanks, one MS/MSD, and one field duplicate collected and submitted for laboratory analyses as shown in Table A.3-1. The blanks and duplicates were assigned individual sample numbers and sent to the laboratory "blind." Additional samples were selected by the laboratory to be analyzed as laboratory duplicates. Documentation related to the collection and analyses of these samples is retained in the project files.

\section{A.4.7.1 Field Quality Control Samples}

Review of the field-collected blank analytical data for the investigation sampling indicates that cross-contamination of acetone from field methods may have occurred during sample collection. Although concentrations were slightly above detection limits, the results did not have an impact on the investigation. Field and equipment rinsate blanks were analyzed for the parameters listed in Table A.3-2 and trip blanks were analyzed for VOCs only.

During the sampling event, one field duplicate soil sample, was sent as a blind sample to the laboratory to be analyzed for the investigation parameters listed in Table A.3-2. For this sample, the duplicate results precision (i.e., RPDs between the environmental sample results and its corresponding field duplicate sample results) was evaluated against the guidelines set forth in EPA Functional Guidelines (EPA, 1994a and 1994b). The EPA Functional Guidelines state that there are no required review criteria for field duplicate analyses comparability, but allow the data reviewer to exercise professional judgement. The RPD between the environmental sample results and its corresponding field duplicate sample results were above the 20 percent criteria stated in the Industrial Sites QAPP (DOE/NV, 1996) for all target analytes.

The laboratory duplicate sample was compared to the criteria set forth in the EPA Functional Guidelines (EPA, 1994a and 1994b) and the associated sample results were qualified accordingly. 
One field sample was selected for use as an MS/MSD sample. The percent recoveries of this sample (a measure of accuracy) and the relative percent difference in the sample results (a measure of precision) were compared to EPA Functional Guideline criteria (EPA, 1994a and 1994b). The results were used to qualify associated environmental sample results accordingly.

The EPA Functional Guidelines for review of organic data state that no data qualification action is taken on the basis of MS/MSD results alone. The data reviewer exercises professional judgement in considering these results in conjunction with the results of laboratory control samples (LCSs) and other QC criteria in applying qualifications to the data.

The inorganic data review in EPA Functional Guidelines allows professional judgement to be applied in evaluating the results of matrix spikes. Generally, if the spike recovery is greater than the upper acceptance limits (>125 percent), non-detections are acceptable for use. If the spike recovery is greater than the upper acceptance limits (>125 percent) or less than the lower acceptance limits ( $<75$ percent), positive results are qualified as estimated $(\mathrm{J})$. If spike recovery falls within the range of 30-74 percent, non-detections are qualified as estimated (UJ). Documentation of data qualification resulting from the application of these guidelines is retained in the subject files.

\section{A.4.7.2 Laboratory Quality Control Samples}

Analysis of method QC blanks and surrogate spikes for organic analyses and method blanks, preparation blanks, initial and continuing calibration blanks for inorganic analyses were performed for each SDG by DataChem Laboratory. The results of these analyses were used to qualify associated environmental sample results according to EPA Functional Guidelines (EPA, 1994a and 1994b).

The EPA Functional Guidelines (EPA, 1994a and 1994b) state that no qualification action is taken if a compound is found in an associated blank, but not in the sample or if a compound is found in the sample, but not in an associated blank. The action taken when a compound is detected in both the sample and the associated blank varies depending upon the analyte involved and is described in the "The 5X/10X Rule." 
For most VOCs, SVOCs, herbicides, pesticides, and PCBs, if an analyte was detected in the sample and was also detected in an associated blank the result is qualified as undetected (U) if the sample concentration is less than five times $(5 \mathrm{X})$ the blank concentration.

For the common laboratory contaminants (e.g., methylene chloride, acetone, 2-butanone [methylethyl ketone or MEK], and phthalate esters [especially bis $\{2$-ethylhexyl $\}$ phthalate]), the factor is raised to ten times (10X) the blank concentration. The sample result is elevated to the quantitation limit if it is less than the quantitation limit or remains unaltered if the sample result is greater than or equal to the quantitation limit.

For inorganics (i.e., metals), sample results greater than the instrument detection limit, but less than five times $(5 \mathrm{X})$ the amount found in an associated blank, are qualified as undetected (U). There are no metallic common laboratory contaminants, so there is no "10X Rule" for metals, and the sample result is never altered. When applying the $5 \mathrm{X}$ criteria to soil sample data or calibration blank data, the raw data results are used to evaluate and qualify the reported results on the Certificate of Analysis.

Surrogate spikes, or system monitoring compounds, are added to the environmental samples analyzed by chromatographic techniques for VOCs, SVOCs, pesticides, PCBs, herbicides, gasoline, and diesel. Surrogate compounds are analytes that are not expected to be present in associated environmental samples, but behave the same as similar target compounds chromatographically. Known amounts of each surrogate are added prior to sample preparation and are carried throughout the preparation/analysis procedure. The percent recoveries of these surrogate compounds give some measure of the anticipated recoveries of the target compounds whose chromatographic behavior they mimic.

If any surrogate percent recoveries are out of the acceptable range (which differs for each surrogate in each method), laboratory protocol calls for the sample to be reprepared and/or reanalyzed. When the surrogate recoveries are acceptable on the second run, only the second analysis results are reported. When both analyses yield the same unacceptable range, the results of both analyses are reported.

The evaluation of surrogate spike percent recovery results is not straightforward. The functional guidelines suggest several optional approaches, but require the data reviewer to exercise professional 
judgement in reviewing surrogate data and qualifying associated data as estimated ( $\mathrm{J}$ or $\mathrm{UJ}$, for detections or nondetections, respectively) or unusable (R).

One laboratory duplicate analysis for metals was performed for each SDG that reported total metals. The duplicate results are compared to the results of the original sample to give a measure of analytical laboratory precision. If the results from a duplicate analysis for a particular analyte fall outside the control limits, the EPA Functional Guidelines for Inorganic Data Review (EPA, 1994a) call for all results for that analyte in all associated samples of the same matrix to be qualified as estimated $(\mathrm{J})$.

Laboratory control samples, also known as blank spikes, consist of known quantities of target compounds added to purified sand or deionized, distilled water, prepared (extracted or digested) and analyzed along with the environmental samples in the sample delivery group. The percent recoveries of the compounds in the LCS give a measure of laboratory accuracy. The functional guidelines call for the data reviewer to use professional judgement to qualify associated data according to established criteria. Documentation of data qualification resulting from the application of these guidelines is retained in the project files.

\section{A.4.8 Field Nonconformances}

During the corrective action investigation, one QA surveillance was conducted by IT Corporation to verify that sampling activities were performed in accordance with applicable requirements. The results of the surveillance indicated no findings, deficiencies, or nonconformances with sampling activities as they met the requirements of the plans and procedures governing the activities at the site. Documentation of these results is retained in project files.

\section{A.4.9 Laboratory Nonconformances}

Laboratory nonconformances are generally due to inconsistencies in analytical instrumentation operation, sample preparations, extractions, and fluctuations in internal standard and calibration results. One laboratory nonconformance was documented for this project. The laboratory 
nonconformance resulted from failure to perform duplicate Sr-90 analysis on samples CSL00002 through CSL00006, CSL00009, CSL00010, and CSL00020. This nonconformance has been accounted for in the data qualification process. Documentation of these results is retained in project files. 


\section{A.5.0 Summary}

Analysis of the data generated from corrective action investigation activities conducted at CAU 232 indicates that sample results for total VOCs, total SVOCs, total RCRA metals, total pesticides, total herbicides, TPH, PCBs, isotopic $\mathrm{U}$, isotopic $\mathrm{Pu}, \mathrm{Sr}-90$, and gamma-emitting radionuclides were below the PALs outlined in the CAIP (DOE/NV, 1999). 


\section{A.6.0 References}

ASTM, see American Society for Testing and Materials.

American Society for Testing and Materials. 1995. Standard Test Method for Strontium-90 in Water, D 5811-95. Philadelphia, PA.

American Society for Testing and Materials. 1997a. Standard Test Method for Isotopic Uranium in Water by Radiochemistry, D-3972-97. Philadelphia, PA.

American Society for Testing and Materials. 1997b. Standard Test Method for Plutonium in Water, D-3865-97. Philadelphia, PA.

DOE, see U.S. Department of Energy.

DOE/NV, see U.S. Department of Energy, Nevada Operations Office.

EPA, see U.S. Environmental Protection Agency.

FFACO, see Federal Facility Agreement and Consent Order.

Federal Facility Agreement and Consent Order. 1996 (as amended). Agreed to by the State of Nevada, the U.S. Department of Energy, and the U.S. Department of Defense.

Hale, G.S., and C.L. Westenburg. 1995. Selected Ground-Water Data for Yucca Mountain Region, Southern Nevada and Eastern California, Calendar Year 1993, USGS-Open-File Report 95-158. Carson City, NV: U.S. Geological Survey.

IT, see IT Corporation.

IT Corporation. 1999. Site-Specific Health and Safety Plan, CAU 232, Area 25 Sewage Lagoons, Nevada Test Site. Las Vegas, NV.

McArthur, R.D., and F.L. Miller, Jr. 1989. Off-Site Radiation Exposure Review Project, Phase II Soil Program, DOE/NV/10384--23. Las Vegas, NV: Desert Research Institute.

NDEP, see Nevada Division of Environmental Protection.

Nevada Division of Environmental Protection. 1994. Water Pollution Control General Permit, GNEV93001. Carson City, NV: Bureau of Federal Facilities.

Nevada Division of Environmental Protection. 1997. Letter from Verae Rosse to Kenneth A. Hoar (DOE/NV) regarding "Revision of General Water Pollution Control Permit," 30 April. Las Vegas, NV. 
Nevada Division of Environmental Protection. 1999. Letter from Paul Liebendorfer to Kenneth A. Hoar (DOE/NV) regarding "Reissuance of Water Pollution Control Permit GNEV93001," 29 October. Carson City, NV: Bureau of Federal Facilities.

REECo, see Reynolds Electrical \& Engineering Company, Inc.

Remote Sensing Laboratory. 1996. Aerial photo number 8811-75 of TCC and Sewage Lagoons. Nellis Air Force Base, NV: Photo Archive Library.

Reynolds Electrical \& Engineering Co., Inc. 1966. Engineering drawing of the Operations Building 3229, Test Cell “C” Sewage Lagoon Plan and Details, number 3229-SP-5. Las Vegas, NV.

Reynolds Electrical \& Engineering Co., Inc. 1968. Engineering drawing of Operations Building 3229, Test Cell “C” Sewer Line-Plan Profile, number 3229-SP-7. Las Vegas, NV.

Reynolds Electrical \& Engineering Co., Inc. 1988. Engineering drawing of the modifications to Test Cell "C" and sewage facility, number 25-TC-C-C41. Las Vegas, NV.

RSL, see Remote Sensing Laboratory.

U.S. Department of Energy. 1997. The Procedures Manual of the Environmental Measurements Laboratory, Vol. 1, 28th Edition. HASL-300-Vol. 1, 28th Edition. Chieco, N.A. (editor). New York, NY.

U.S. Department of Energy, Nevada Operations Office. 1996. Industrial Sites Quality Assurance Project Plan, Nevada Test Site, Nevada, Rev. 1, DOE/NV--372. Las Vegas, NV.

U.S. Department of Energy, Nevada Operations Office. 1999. Corrective Action Investigation Plan for CAU 232, Area 25 Sewage Lagoons, Nevada Test Site, Nevada, Rev. 0, DOE/NV--545. Las Vegas, NV.

U.S. Ecology and Atlan-Tech. 1992. Environmental Monitoring Report for the Proposed Ward Valley California Low Level Radioactive Waste (LLRW) Facility. Rosewell, GA: Atlan-Tech, Inc.

U.S. Environmental Protection Agency. 1980. Prescribed Procedures for Measurements of Radioactivity in Drinking Water, EPA-600/4-80-032. Washington, DC.

U.S. Environmental Protection Agency. 1987. Data Quality Objectives for Remedial Response Activities, EPA/540/G-87-003. Washington, DC.

U.S. Environmental Protection Agency. 1994a. Contract Laboratory Program National Functional Guidelines for Inorganic Data Review, EPA 540/R-94/013. Washington, DC. 
U.S. Environmental Protection Agency. 1994b. Contract Laboratory Program National Functional Guidelines for Organic Data Review, EPA 540/R-94/012. Washington, DC.

U.S. Environmental Protection Agency. 1994c. Guidance for the Data Quality Objectives Process, EPA QA/G-4. Washington, DC.

U.S. Environmental Protection Agency. 1996. Test Methods for Evaluating Solid Waste, Physical/Chemical Methods, SW-846, CD-ROM PB97-501928GEI, CD ROM contains updates for 1986, 1992, 1994 and 1996. Washington, DC.

U.S. Environmental Protection Agency. 1998. Memo from S.J. Smucker to PRG Table Mailing List regarding Region 9 Preliminary Remediation Goals (PRGs), 1 August. San Francisco, CA. 


\section{Appendix B}

\section{Response to NDEP Comments}




\section{NEVADA ENVIRONMENTAL RESTORATION PROJECT DOCUMENT REVIEW SHEET}

\begin{tabular}{|c|c|c|c|c|c|}
\hline \multicolumn{4}{|c|}{$\begin{array}{l}\text { 1. Document Title/Number: Draft Corrective Action Decision Document/Closure Report for Corrective Action } \\
\text { Unit 232: Area } 25 \text { Sewage Lagoons, Nevada Test Site, Nevada }\end{array}$} & \multicolumn{2}{|l|}{ 2. Document Date: October 1999} \\
\hline \multicolumn{4}{|c|}{ 3. Revision Number: 0} & \multicolumn{2}{|c|}{ 4. Originator/Organization: IT Corporation } \\
\hline \multicolumn{4}{|c|}{ 5. Responsible DOE/NV ERP Project Mgr.: Janet Appenzeller-Wing } & \multicolumn{2}{|l|}{ 6. Date Comments Due: } \\
\hline \multicolumn{6}{|c|}{ 7. Review Criteria: Full } \\
\hline \multicolumn{4}{|c|}{ 8. Reviewer/Organization/Phone No.: Gregory A. Raab, NDEP, 486-2867 } & \multicolumn{2}{|l|}{ 9. Reviewer's Signature: } \\
\hline $\begin{array}{l}\text { 10. Comment } \\
\text { Number/ } \\
\text { Location }\end{array}$ & 11. Type* & 12. Comment & \multicolumn{2}{|c|}{ 13. Comment Response } & 14. Accept \\
\hline 1) General & & $\begin{array}{l}\text { This document contains no information as to whether the CAU } 232 \\
\text { primary lagoon had been in operation under the Water Pollution } \\
\text { Control general permit, and, if so, when it had been placed on inac- } \\
\text { tive status and subsequently removed from the permit. } \\
\text { There is no documentation of the removal and disposal of the } \\
\text { sludge. Since this lagoon did contain sewage in the past, DOE must } \\
\text { demonstrate that there is no pathogenic organism potential at this } \\
\text { site if sludges remain. There is no documentation of the removal } \\
\text { and disposal of the sludge. These clarifications must be included in } \\
\text { the Final CADD/CR. }\end{array}$ & \multicolumn{2}{|c|}{$\begin{array}{l}\text { The sewage lagoons were in operation under the Water Pol- } \\
\text { lution Control General Permit effective February } 1,1994 \text {, } \\
\text { and removed in Revision } 3 \text { of the permit in a letter from } \\
\text { NDEP to DOE, dated April } 4,1997 \text {. The current permit } \\
\text { effective November } 13,1999 \text {, shows that the site is not on } \\
\text { the permit. This information has been included in Section } \\
\text { A.2.1. } \\
\text { After discussion between NDEP and DOE/NV ERD } \\
\text { representatives, the request for analysis for pathogenic } \\
\text { organisms was retracted. Sections } 2.1 \text { and A.2.1 of the } \\
\text { CADD/CR have been modified to indicate that currently } \\
\text { there is no evidence of sludge in the lagoons. }\end{array}$} & In Part \\
\hline $\begin{array}{l}\text { 2) Page } 7 \text { of } 8 \text {, } \\
\text { 1st Bullet }\end{array}$ & & $\begin{array}{l}\text { "No further corrective actions be required." This statement is } \\
\text { negated by bullet four, "Best management practice activities are as } \\
\text { follows:..." closing off piping leading to the sewage lagoons and } \\
\text { swale... Clean closure of CAU } 232 \text { cannot be affected until the } \\
\text { items under bullet four are completed; e.g., piping leading to the } \\
\text { sewage lagoons and swale are closed off. DOE must resolve this } \\
\text { issue before the Final CADD/CR will be approved (See } \\
\text { comment \#4). }\end{array}$ & \multicolumn{2}{|c|}{$\begin{array}{l}\text { The best management practice activities discussed in the } \\
\text { draft CADD/CR have since been completed. Changes to } \\
\text { Sections } 2.3 \text { of the CADD/CR reflect current site conditions. }\end{array}$} & Accepted \\
\hline
\end{tabular}




\section{NEVADA ENVIRONMENTAL RESTORATION PROJECT DOCUMENT REVIEW SHEET}

Document Title/Number: Draft Corrective Action Decision Document/Closure Report for Corrective Action Unit 232: Area 25 Sewage Lagoons, Nevada Test Site, Nevada

Reviewer/Organization: Gregory A. Raab, NDEP, 486-2867

\begin{tabular}{|c|c|c|c|c|}
\hline $\begin{array}{l}\text { 10. Comment } \\
\text { Number/ } \\
\text { Location }\end{array}$ & 11. Type* & 12. Comment & 13. Comment Response & 14. Accept \\
\hline $\begin{array}{l}\text { 3) Page } 7 \text { of } 8 \text {, } \\
\text { 2nd Paragraph }\end{array}$ & & $\begin{array}{l}\text { "...A Notice of Completion to DOE/NV is requested from NDEP for } \\
\text { the clean closure of CAU } 232 . . . \text {. Since the work proposed has not } \\
\text { been completed, NDEP cannot issue a Notice of Completion for two } \\
\text { reasons...1) DOE is proposing clean closure, 2) the work has not } \\
\text { been completed. }\end{array}$ & $\begin{array}{l}\text { Section } 3.0 \text {, second paragraph has been modified to indi- } \\
\text { cate that DOE/NV is requesting no further action. } \\
\text { The best management activities have been completed. } \\
\text { These activities are discussed in Sections } 2.3 \text {. }\end{array}$ & Accepted \\
\hline $\begin{array}{l}\text { 4) Page } 7 \text { of } 8 \text {, } \\
\text { Last Sentence }\end{array}$ & & $\begin{array}{l}\text { "...No use restrictions are required to be placed on the CAU...". } \\
\text { COCs discovered at this site were compared to the EPA's } \\
\text { industrial-use PRGs. This site will have an industrial-use LUR } \\
\text { unless it can be shown that the COCs at this site meet the } \\
\text { residential-use PRGs. }\end{array}$ & $\begin{array}{l}\text { Discussions between Janet Appenzeller-Wing (DOE/NV } \\
\text { ERD) and Paul Liebendorfer (NDEP) indicate that this } \\
\text { document will not be altered with respect to this comment. } \\
\text { Note that all detected constituents are less than the } \\
\text { residential-use PRGs with the exception of arsenic. Arsenic } \\
\text { is within the typical background range for soils in the area; } \\
\text { therefore, the arsenic concentrations detected at CAU } 232 \\
\text { represent ambient conditions and not contamination. }\end{array}$ & Accepted \\
\hline
\end{tabular}

${ }^{a}$ Comment Types: $M=$ Mandatory, $S=$ Suggested.

Return Document Review Sheets to DOE/NV Environmental Restoration Division, Attn: QAC, M/S 505. 


\section{Distribution}

*Provide copy in distribution of Revision 0 and subsequent revisions if applicable.

Copies of the NDEP-approved document will be distributed to others.

Paul J. Liebendorfer

State of Nevada

Bureau of Federal Facilities

Division of Environmental Protection

333 W. Nye Lane, Room 138

Carson City, NV 89706-0851

Mike McKinnon

State of Nevada

Bureau of Federal Facilities

Division of Environmental Protection

555 E. Washington, Suite 4300

Las Vegas, NV 89101

Sabrina Lawrence

Environmental Restoration Division

DOE/Nevada Operations Office

P.O. Box 98518, M/S 505

Las Vegas, NV 89193-8518

Janet Appenzeller-Wing

Environmental Restoration Division

DOE/Nevada Operations Office

P.O. Box 98518, M/S 505

Las Vegas, NV 89193-8518

Sabine Curtis

Environmental Restoration Division

DOE/Nevada Operations Office

P.O. Box 98518, M/S 505

Las Vegas, NV 89193-8518

Jerry Bonn

Bechtel Nevada

P.O. Box 98521, M/S NTS306

Las Vegas, NV 89193-8521
2 (Controlled)*

1 (Controlled)*

1 (Controlled)*

1 (Uncontrolled)*

1 (Uncontrolled)*

1 (Uncontrolled)* 
Wayne Johnson

Bechtel Nevada

P.O. Box 98521, M/S NTS306

Las Vegas, NV 89193-8521

Linda Linden

SAIC

P.O. Box 93838

Las Vegas, NV 89193

Dustin Wilson

SAIC

P.O. Box 93838

Las Vegas, NV 89193

IT Corporation Central Files

IT Corporation

P.O. Box 93838

Las Vegas, NV 89193

Technical Information Resource Center

DOE/Nevada Operations Office

IT Corporation

P.O. Box 93838

Las Vegas, NV 89193

U.S. Department of Energy

Office of Scientific and Technical Information

P.O. Box 62

Oak Ridge, TN 37831

Manager Southern Nevada FFACO

Public Reading Room

P.O. Box 98521, M/S NLV040

Las Vegas, NV 89193-8521

Manager Northern Nevada FFACO

Public Reading Room

c/o Rosa Silver

IT Corporation

P.O. Box 93838

Las Vegas, NV 89193
1 (Uncontrolled)*

1 (Uncontrolled)*

1 (Uncontrolled)*

1 (Uncontrolled)*

1 (Uncontrolled)

1 (Uncontrolled, electronic copy)

1 (Controlled)

1 (Uncontrolled)

1 (Uncontrolled) 
CAU 232 CADD/CR

Distribution

Revision: 0

Date: $12 / 23 / 99$

Page 3 of 3

FFACO Public Reading Rooms Coordinator

1 (Controlled)

Rosa Silver

IT Corporation

P.O. Box 93838

Las Vegas, NV 89193 